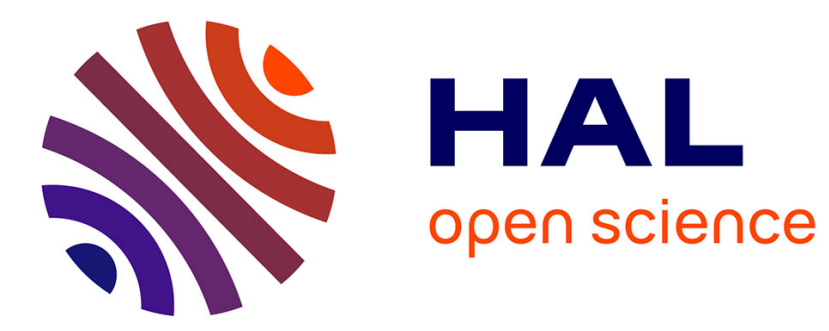

\title{
Stepwise Solar Methane Reforming and Water-Splitting via Lattice Oxygen Transfer in Iron and Cerium Oxides
}

Srirat Chuayboon, Stéphane Abanades, Sylvain Rodat

\section{To cite this version:}

Srirat Chuayboon, Stéphane Abanades, Sylvain Rodat. Stepwise Solar Methane Reforming and WaterSplitting via Lattice Oxygen Transfer in Iron and Cerium Oxides. Energy Technology, 2020, 8 (8), pp.1900415. 10.1002/ente.201900415 . hal-02573272

\section{HAL Id: hal-02573272 \\ https://hal.science/hal-02573272}

Submitted on 5 Nov 2020

HAL is a multi-disciplinary open access archive for the deposit and dissemination of scientific research documents, whether they are published or not. The documents may come from teaching and research institutions in France or abroad, or from public or private research centers.
L'archive ouverte pluridisciplinaire HAL, est destinée au dépôt et à la diffusion de documents scientifiques de niveau recherche, publiés ou non, émanant des établissements d'enseignement et de recherche français ou étrangers, des laboratoires publics ou privés. 


\section{WILEY-VCH}

Stepwise solar methane reforming and water-splitting via lattice oxygen transfer in iron and cerium oxides

Srirat Chuayboon, Stéphane Abanades", Sylvain Rodat

Dr. S. Abanades

Processes, Materials and Solar Energy Laboratory, PROMES-CNRS, 7 Rue du Four Solaire, 66120 Font-Romeu, France

E-mail: stephane.abanades@promes.cnrs.fr

S. Chuayboon

Processes, Materials and Solar Energy Laboratory, PROMES-CNRS, 7 Rue du Four Solaire, 66120 Font-Romeu, France

Department of Mechanical Engineering, King Mongkut's Institute of Technology Ladkrabang, Prince of Chumphon Campus, Chumphon 86160, Thailand

Dr. S. Rodat

Univ. Grenoble Alpes, INES, BP 332, 50 Avenue du Lac Léman, F-73375 Le-Bourget-du-lac, France. CEA-LITEN Laboratoire des Systèmes Solaires Haute Température (LSHT), F-38054 Grenoble, France

Keywords: (concentrated solar energy, chemical looping, ceria, iron oxide, syngas)

Abstract. Chemical looping reforming of methane (CLRM) involves lattice oxygen transfer in metal oxides. This study aims to compare iron $\left(\mathrm{Fe}_{2} \mathrm{O}_{3}\right)$ and cerium $\left(\mathrm{CeO}_{2}\right)$ oxides as oxygen carrier materials for isothermal solar-driven stepwise $\mathrm{CH}_{4}$ reforming and $\mathrm{H}_{2} \mathrm{O}$ splitting. Experiments were conducted in a directly-irradiated lab-scale solar reactor heated by concentrated sunlight in the temperature range $950-1150{ }^{\circ} \mathrm{C}$. Using solar energy for process heat reduces the dependence on fossil energy resources and avoids $\mathrm{CO}_{2}$ emissions, while converting solar energy into chemical fuels. The performance of the oxygen carrier materials was compared and evaluated by determining the averaged amount of oxygen transferred, methane conversion, syngas yield, and thermochemical cycling stability. As a result, iron oxide reduction with methane strongly depended on temperature and displayed relatively lower reaction rate than $\mathrm{CeO}_{2}$. The reduced iron $(\mathrm{Fe})$ was not completely re-oxidized to iron oxide $\left(\mathrm{Fe}_{3} \mathrm{O}_{4}\right)$ after water-splitting step because of its low thermal stability resulting in strong 


\section{WILEY-VCH}

sintering and agglomeration, thereby decreasing syngas yield and eventually leading to material deactivation. In contrast, cerium oxide exhibited faster reaction rate and stable syngas yield with $\mathrm{H}_{2} / \mathrm{CO}$ molar ratio approaching two over repeated cycles. Stable patterns in the averaged oxygen nonstoichiometry $(\delta=0.35-0.38)$, methane conversion $\left(\mathrm{X}_{\mathrm{CH}_{4}}=46.9\right.$ $60.9 \%$ ), and total syngas yield $\left(5.67-6.80 \mathrm{mmol} / \mathrm{g}_{\mathrm{CeO}_{2}}\right.$ for reduction and $2.38-2.57 \mathrm{mmol} / \mathrm{g}_{\mathrm{CeO}_{2}}$ for oxidation) over twelve successive cycles for ceria reticulated foam demonstrated excellent thermal cycling stability. Thus, employing $\mathrm{Fe}_{2} \mathrm{O}_{3}$ as oxygen carrier was not suitable for solar CLRM, but iron oxide reduction with methane could be a promising option for solar metallurgy aiming at producing both metallic iron and syngas.

\section{Introduction}

Synthesis gas (syngas) is widely considered as one of the most important valuable chemical energy carriers as it is a key intermediate resource to produce hydrogen, ammonia, methanol, or synthetic hydrocarbon fuels. The syngas can be produced from a variety of sources, including either renewable (biomass) or fossil sources (natural gas, coal, or any hydrocarbon feedstock), by partial oxidation reactions with steam or oxygen. Methane reforming is the conventional method for producing syngas. Steam ${ }^{[1]}$ and dry reforming ${ }^{[2-5]}$ are two possible routes for methane reforming:

Steam reforming: $\mathrm{CH}_{4}+\mathrm{H}_{2} \mathrm{O} \rightarrow 3 \mathrm{H}_{2}+\mathrm{CO} \quad \Delta \mathrm{H}^{0}=+206 \mathrm{~kJ} / \mathrm{mol}$

Dry reforming: $\mathrm{CH}_{4}+\mathrm{CO}_{2} \rightarrow 2 \mathrm{H}_{2}+2 \mathrm{CO} \quad \Delta \mathrm{H}^{0}=+247 \mathrm{~kJ} / \mathrm{mol}$

Both reactions are highly endothermic, and the required energy to drive these reactions is generally supplied by the combustion of fossil fuels, resulting in greenhouse gas emissions, especially $\mathrm{CO}_{2}$ responsible for climate change and global warming. Using solar energy in 


\section{WILEY-VCH}

place of fossil fuels for supplying process heat thus represents a suitable option to alleviate these issues.

Alternatively, a promising modern pathway to produce clean syngas is the utilization of metal oxide redox pairs for partial oxidation of methane (namely, chemical looping reforming of methane, CLRM) using concentrated solar energy to drive endothermic reactions ${ }^{[6-9]}$ Such a process usually encompasses two steps: (1) partial oxidation of methane along with metal oxide reduction, and (2) re-oxidation of the oxide with steam $\left(\right.$ or $\mathrm{CO}_{2}$ ) to produce pure $\mathrm{H}_{2}$ (or $\mathrm{CO})$. The advantages of solar CLRM over metal oxides when compared to the conventional process are: (1) the discharge of pollutants is totally avoided, as the required heat is provided by solar energy ${ }^{[10-13]}$, (2) the use of catalysts is bypassed, eliminating deactivation issues, (3) the supply of gaseous oxygen associated with the need for upstream air separation for oxygen production are eliminated, (4) isothermal cycle operation is made possible $\left(\sim 1000^{\circ} \mathrm{C}\right)$, avoiding sensible heat losses and reactor materials issues ${ }^{[14]}$, (5) syngas is produced with $\mathrm{H}_{2} / \mathrm{CO}$ ratio of two, suitable for methanol synthesis, and (6) carbon deposition on redox materials is inherently eliminated during oxidation step (carbon gasification with $\mathrm{H}_{2} \mathrm{O}$ or $\mathrm{CO}_{2}$ ), thus avoiding oxygen carriers deactivation.

The possibility of utilizing metal oxides as oxygen carriers for $\mathrm{CH}_{4}$ partial oxidation has been experimentally reported. The materials include either volatile metal oxides such as $\mathrm{ZnO}^{[10,15]}$ and $\mathrm{MgO}^{[16]}$, or non-volatile oxides such as $\mathrm{WO}_{3}{ }^{[12]}$, ceria $\left(\mathrm{CeO}_{2}\right)^{[17,18]}$, cerium-based oxides $^{[19-24]}$, and iron oxide ${ }^{[25-27]}$. Cerium and iron oxides are particularly attractive because of their different physical and chemical properties. ${ }^{[28]}$ Ceria keeps a stable cubic fluorite structure during large changes in oxygen non-stoichiometries (reduction extents), and exhibits rapid oxygen storage/release through lattice transfer ${ }^{[29-32]}$ On the other hand, iron oxide $\left(\mathrm{Fe}_{2} \mathrm{O}_{3}\right)$ is abundant and low cost, and exhibits large oxygen releasing ability compared to $\mathrm{CeO}_{2}$ and other candidates, but it may encounter sintering issues, leading to low cycling stability. ${ }^{[33,34]}$ The main motivation of using iron oxide for CLRM is thus related to process 


\section{WILEY-VCH}

cost reduction because of large material availability, compared to cerium oxide. Moreover, the sintering issue of iron oxide may be counterbalanced by its superior fuel production capability due to reactions involving multivalent iron species $\left(\mathrm{Fe}, \mathrm{FeO}, \mathrm{Fe}_{3} \mathrm{O}_{4}\right)$, thus potentially leading to higher amounts of oxygen transferred during redox reactions. Conversely, the exchanged oxygen and fuel productivity from ceria are determined by the reduction extent corresponding to the achieved non-stoichiometry (amount of oxygen vacancies in $\mathrm{CeO}_{2-\delta}$, which is always lower than $\left.\delta_{\max }=0.5 \mathrm{~mol}_{\mathrm{O}} / \mathrm{mol}_{\mathrm{CeO}_{2}}\right)$. Thus, evaluation and comparison of the materials reactivity for fuel production upon cycling under real solar irradiation conditions is necessary to identify the most suitable one.

Otsuka et al. first investigated the partial oxidation of $\mathrm{CH}_{4}$ over ceria in a fixed bed quartz tubular reactor (non-solar). ${ }^{[18]}$ They showed that the use of ceria enables the direct conversion of $\mathrm{CH}_{4}$ into syngas, and the reaction provides an appropriate syngas composition $\left(\mathrm{H}_{2} / \mathrm{CO}=2\right)$. Besides, the ceria redox cycle was coupled with the utilization of concentrated solar energy for producing $\mathrm{H}_{2}$ from two-step thermochemical water-splitting, as first proposed by Abanades and Flamant. ${ }^{[35]}$ Thermodynamic and experimental analysis of solar-driven methane reforming over ceria were also investigated. ${ }^{[6,30,36]}$ Maximum predicted solar-to-fuel efficiency of $40 \%$ was reported for partial oxidation of methane with ceria during isothermal cycling at $950{ }^{\circ} \mathrm{C}^{[37]}$, and the maximum projected solar-to-fuel thermal efficiency of $27 \%$ for cycling at $1000{ }^{\circ} \mathrm{C}$ was later identified ${ }^{[8]}$. Solar CLRM in a prototype reactor operated in a high-flux solar simulator was performed with solar-to-fuel efficiency of $7 \%$ and thermal efficiency of 25\%. ${ }^{[9]}$ Concerning iron oxides, Steinfeld et al. examined the $\mathrm{Fe}_{3} \mathrm{O}_{4}+4 \mathrm{CH}_{4}$ system and reported that the chemical equilibrium species consist of metallic iron in the solid phase and a mixture of $67 \% \mathrm{H}_{2}$ and $33 \% \mathrm{CO}$ in the gaseous phase (at 1 bar and $1027^{\circ} \mathrm{C}$ ), while showing experimentally that the reduction of $\mathrm{Fe}_{3} \mathrm{O}_{4}$ with $\mathrm{CH}_{4}$ is strongly dependent on temperature and residence time. ${ }^{[27]} \mathrm{Lu}$ et al. investigated the reactivity of magnetite $\left(\mathrm{Fe}_{3} \mathrm{O}_{4}\right)$ with respect to $\mathrm{CH}_{4}$ reforming and $\mathrm{H}_{2} \mathrm{O}$ splitting in a continuous prototype. ${ }^{[33]}$ The reduction 


\section{WILEY-VCH}

kinetics was also studied with both fresh and recycled magnetite. The hydrogen yields from the original and calcinated magnetite after successive cycling were 4.94 and $5.25 \mathrm{mmol} / \mathrm{g}$, respectively, and the activation energy for the reduction was $93 \mathrm{~kJ} / \mathrm{mol}$. In addition, Bleeker et al. studied the deactivation of iron oxide used in the steam-iron process to produce hydrogen and reported that the main drawback of using iron oxide is the inherent structural changes that take place during oxygen loading and unloading, leading to severe deactivation due to loss of specific surface area. ${ }^{[34]}$

The performance comparison of the oxygen carrier materials in a solar reactor using representative operating conditions has not been performed so far. In the present work, the CLRM process is performed in a directly-irradiated lab-scale solar reactor using iron and cerium oxides with different structures (packed-bed powder and reticulated porous foam). High-temperature concentrated solar heat is used to provide the reaction enthalpy, and therefore the feedstock is entirely dedicated to produce $\mathrm{H}_{2}$ and $\mathrm{CO}$ (syngas). Solar energy is thus stored into a high-quality syngas and can easily be transported for later use as a convertible and dispatchable chemical form. Solar CLRM promotes methane valorization and offers an efficient means of storing intermittent solar energy into renewable solar fuels. The relevant performance metrics of the process are quantified including lattice oxygen transfer $\left(\mathrm{n}_{\mathrm{O}}\right)$ and average oxygen non-stoichiometry $(\delta)$, methane conversion $\left(\mathrm{X}_{\mathrm{CH}_{4}}\right)$, syngas yield, and thermochemical cycling stability in order to compare the influence of oxygen carrier materials on solar reactor performance. In addition, the demonstration of the whole two-step solar process in a solar reactor operated with a real solar concentrating system is presented with determination of the fuel production capacity during both steps.

\section{Thermodynamics}

\subsection{Iron oxide}




\section{WILEY-VCH}

The endothermic reduction reaction of iron oxide $\left(\mathrm{Fe}_{2} \mathrm{O}_{3}\right)$ with $\mathrm{CH}_{4}$ is composed of successive steps:

$\mathrm{Fe}_{2} \mathrm{O}_{3}+1 / 3 \mathrm{CH}_{4} \longrightarrow 2 / 3 \mathrm{Fe}_{3} \mathrm{O}_{4}+2 / 3 \mathrm{H}_{2}+1 / 3 \mathrm{CO}$

$2 / 3 \mathrm{Fe}_{3} \mathrm{O}_{4}+2 / 3 \mathrm{CH}_{4} \longrightarrow 2 \mathrm{FeO}+4 / 3 \mathrm{H}_{2}+2 / 3 \mathrm{CO}$

$2 \mathrm{FeO}+2 \mathrm{CH}_{4} \rightarrow 2 \mathrm{Fe}+4 \mathrm{H}_{2}+2 \mathrm{CO}$

The summation of the above reactions corresponds to:

$\mathrm{Fe}_{2} \mathrm{O}_{3}+3 \mathrm{CH}_{4} \rightarrow 2 \mathrm{Fe}+6 \mathrm{H}_{2}+3 \mathrm{CO} \quad \Delta \mathrm{H}^{0}=715 \mathrm{~kJ} / \mathrm{mol}$

Possible side reactions related to methane cracking and direct reaction of $\mathrm{Fe}_{2} \mathrm{O}_{3}$ with carbon may also occur during iron oxide reduction with methane:

$\mathrm{CH}_{4} \rightarrow \mathrm{C}+2 \mathrm{H}_{2}$

$\mathrm{Fe}_{2} \mathrm{O}_{3}+3 \mathrm{C} \rightarrow 2 \mathrm{Fe}+3 \mathrm{CO}$

The exothermic oxidation reaction of metallic iron with $\mathrm{H}_{2} \mathrm{O}$ is represented as $\left(\mathrm{Fe}_{3} \mathrm{O}_{4}\right.$ reoxidation to $\mathrm{Fe}_{2} \mathrm{O}_{3}$ with $\mathrm{H}_{2} \mathrm{O}$ is not thermodynamically possible):

$3 \mathrm{Fe}+4 \mathrm{H}_{2} \mathrm{O} \rightarrow \mathrm{Fe}_{3} \mathrm{O}_{4}+4 \mathrm{H}_{2} \quad \Delta \mathrm{H}^{0}=-151 \mathrm{~kJ} / \mathrm{mol}$

Possible side reactions during oxidation step are carbon deposition gasification with $\mathrm{H}_{2} \mathrm{O}$ :

$\mathrm{C}+\mathrm{H}_{2} \mathrm{O} \rightarrow \mathrm{CO}+\mathrm{H}_{2}$ 
The thermodynamic feasibility of chemical reactions involving iron oxide species reduction with methane can be assessed from the Gibbs free enthalpy change $\left(\Delta \mathrm{G}^{\circ}\right)$ (Figure 1). The $\Delta \mathrm{G}^{\circ}$ values decrease with temperature $\left(\Delta \mathrm{G}^{\circ}\right.$ equals zero at $400{ }^{\circ} \mathrm{C}$ for $3 \mathrm{Fe}_{2} \mathrm{O}_{3}+\mathrm{CH}_{4}$, and at above $600{ }^{\circ} \mathrm{C}$ for the other reactions), which means that all the reduction reactions are thermodynamically favorable when increasing the temperature.

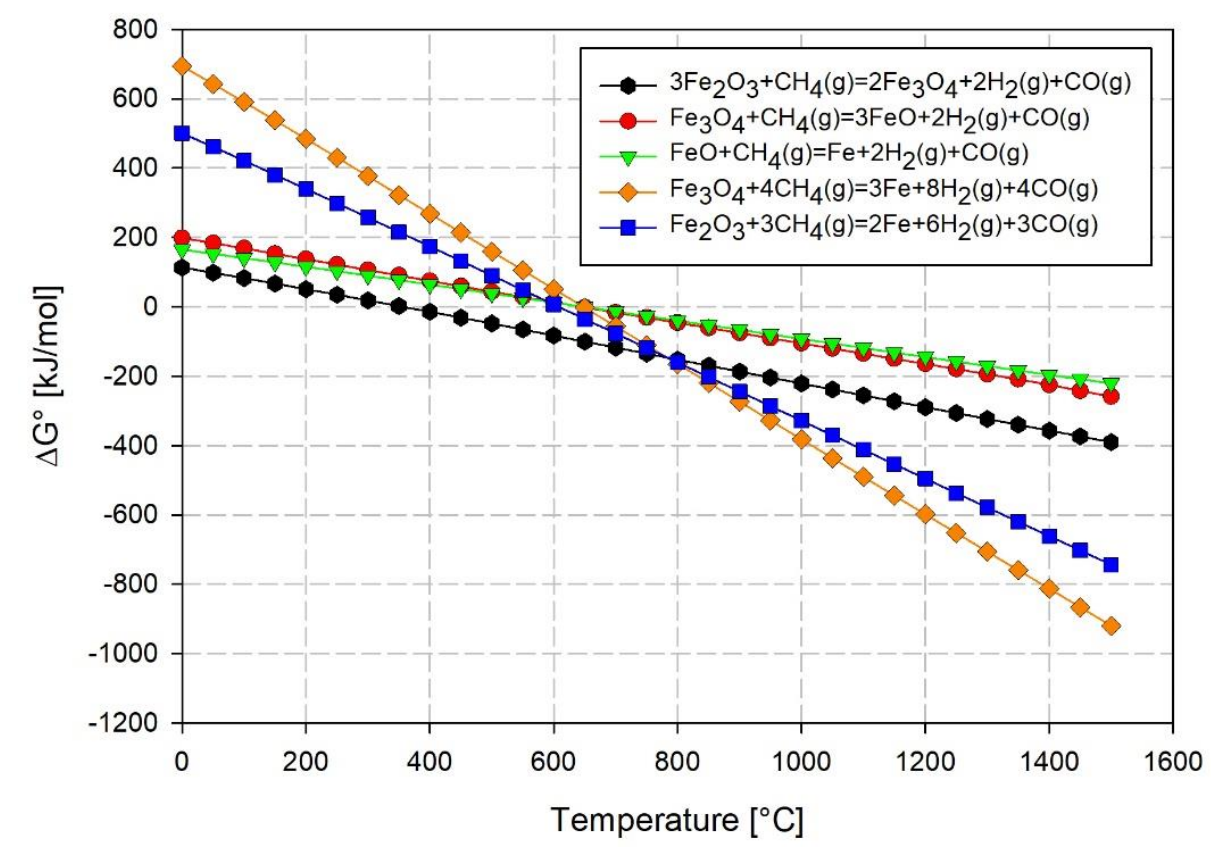

Figure 1. $\Delta \mathrm{G}^{\circ}$ variations for iron oxides reduction with methane as a function of temperature.

Regarding the possible side reactions (Figure 2), the direct reductions of $\mathrm{Fe}_{3} \mathrm{O}_{4}$ with $\mathrm{C}$ and $\mathrm{H}_{2}$ are thermodynamically favorable $\left(\mathrm{Fe}_{3} \mathrm{O}_{4}+2 \mathrm{C}\right.$ and $\mathrm{Fe}_{3} \mathrm{O}_{4}+4 \mathrm{C}$ proceed spontaneously at above $700{ }^{\circ} \mathrm{C}$, and $\mathrm{Fe}_{3} \mathrm{O}_{4}+4 \mathrm{H}_{2}$ proceeds at above $1100{ }^{\circ} \mathrm{C}$ ). In contrast, the direct reduction of $\mathrm{Fe}_{3} \mathrm{O}_{4}$ with $\mathrm{CO}$ is not thermodynamically possible. 


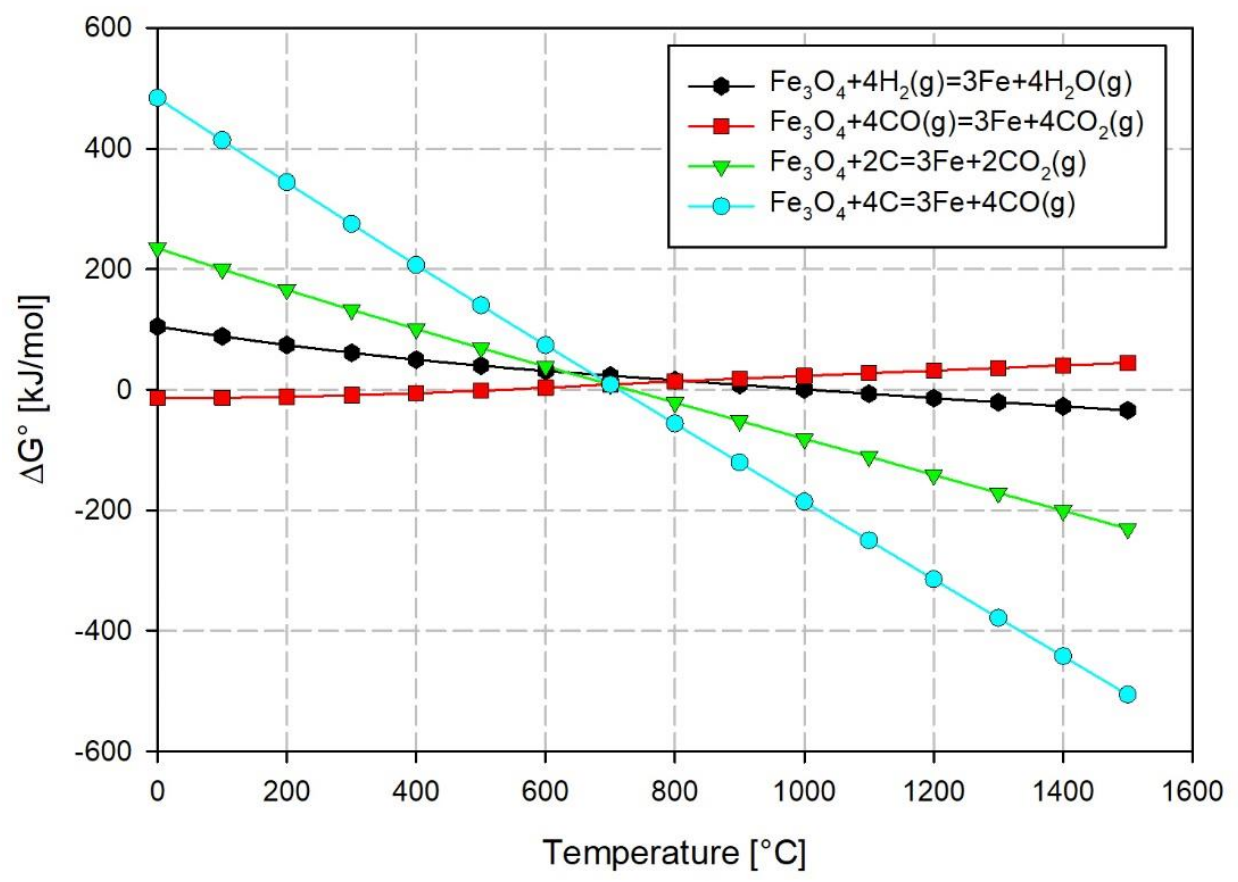

Figure 2. $\Delta \mathrm{G}^{\circ}$ variations for the reactions of $\mathrm{Fe}_{3} \mathrm{O}_{4}$ with $\mathrm{H}_{2}, \mathrm{CO}$, and $\mathrm{C}$ as a function of temperature.

The thermodynamic equilibrium composition was calculated with HSC Chemistry to appraise the species distribution and system composition as a function of temperature. It provides a realistic overview of the chemical product species and the most favorable conditions for carrying out the reduction reaction with $\mathrm{CH}_{4}$ and reaching completion. The main assumptions of the method must be reminded, including closed system approach without any gas flow and available thermodynamic properties for any chemical species to represent the system as closely as possible.

The equilibrium species composition of $\mathrm{Fe}_{2} \mathrm{O}_{3}+3 \mathrm{CH}_{4}$ at 1 bar as a function of temperature is shown in Figure 3 (and in Figure $\mathbf{S 1}$ for $\mathrm{Fe}_{3} \mathrm{O}_{4}+4 \mathrm{CH}_{4}$ ). $\mathrm{Fe}_{2} \mathrm{O}_{3}$ is first reduced to $\mathrm{Fe}_{3} \mathrm{O}_{4}$ while methane is decomposed to $\mathrm{C}$ and $\mathrm{H}_{2}$ when the temperature exceeds $400{ }^{\circ} \mathrm{C}$. Then, $\mathrm{Fe}_{3} \mathrm{O}_{4}$ is reduced to $\mathrm{FeO}$, along with intermediate non-stoichiometric species $\left(\mathrm{Fe}_{0.945} \mathrm{O}, \mathrm{Fe}_{0.947} \mathrm{O}\right.$, and $\mathrm{FeO}_{1.056}$ ) while $\mathrm{H}_{2}, \mathrm{C}$, and $\mathrm{H}_{2} \mathrm{O}(\mathrm{g})$ become the main product components. Above $400{ }^{\circ} \mathrm{C}, \mathrm{FeO}$ 


\section{WILEY-VCH}

starts reducing into $\mathrm{Fe}$, along with $\mathrm{CO}$ and $\mathrm{CO}_{2}$ formation. Complete reduction to $\mathrm{Fe}$ is

reached above $700{ }^{\circ} \mathrm{C}$, while $\mathrm{C}, \mathrm{H}_{2} \mathrm{O}$, and $\mathrm{CO}_{2}$ decrease constantly. Finally, the main products are both $\mathrm{H}_{2}$ and $\mathrm{CO}$ with $\mathrm{H}_{2} / \mathrm{CO}$ ratio approaching two, and $\mathrm{Fe}$ above $1000{ }^{\circ} \mathrm{C}$.

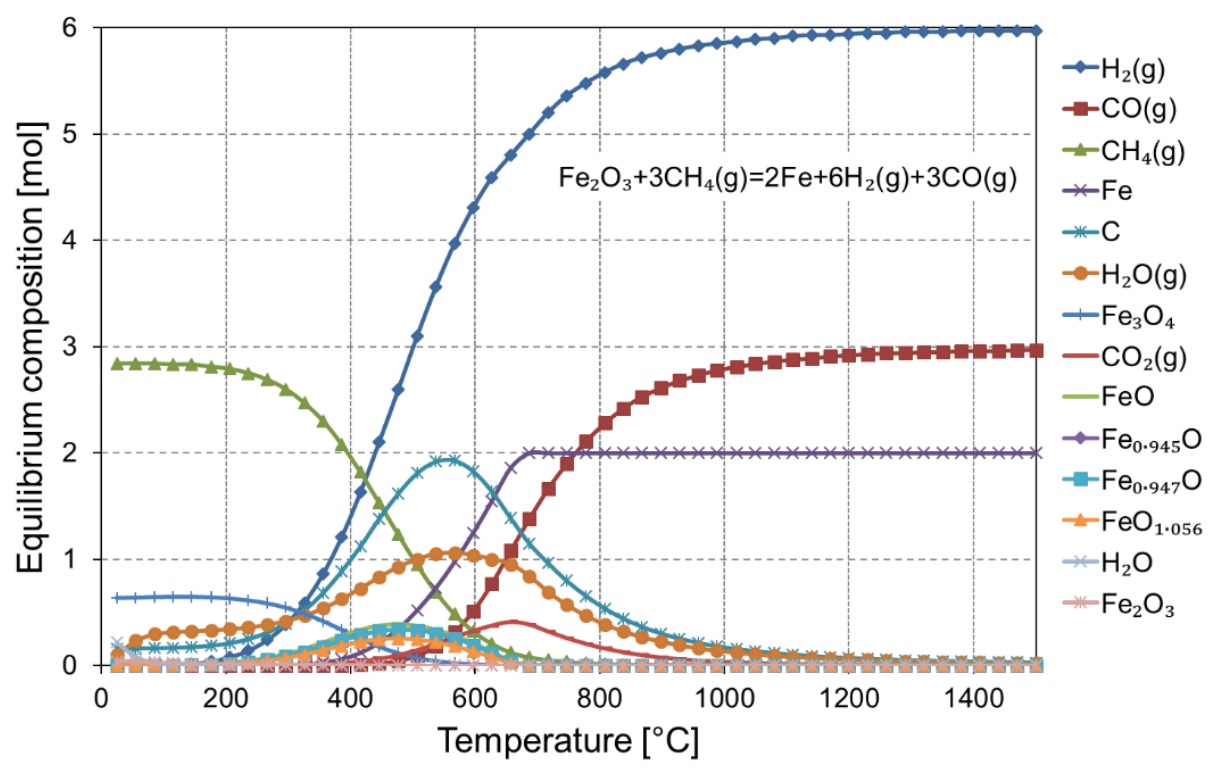

Figure 3. Thermodynamic equilibrium composition of methane reforming over $\mathrm{Fe}_{2} \mathrm{O}_{3}$ as a function of temperature at 1 bar.

Regarding carbothermal reduction of $\mathrm{Fe}_{2} \mathrm{O}_{3}$ in Figure 4 (and Figure $\mathbf{S 2}$ for $\mathrm{Fe}_{3} \mathrm{O}_{4}+4 \mathrm{C}$ ), $\mathrm{Fe}_{2} \mathrm{O}_{3}$ is first reduced to $\mathrm{Fe}_{3} \mathrm{O}_{4}$ along with the formation of $\mathrm{CO}_{2}$ above $200{ }^{\circ} \mathrm{C}$. Subsequently, $\mathrm{Fe}_{3} \mathrm{O}_{4}$ is reduced to $\mathrm{FeO}$ and non-stoichiometric compounds $\left(\mathrm{Fe}_{0.945} \mathrm{O}, \mathrm{Fe}_{0.947} \mathrm{O}\right.$, and $\left.\mathrm{FeO}_{1.056}\right)$ above $400{ }^{\circ} \mathrm{C}$, and $\mathrm{FeO}$ is finally reduced to $\mathrm{Fe}$ along with $\mathrm{CO}$ formation above $500{ }^{\circ} \mathrm{C}$. Reduction to Fe reaches completion at above $800{ }^{\circ} \mathrm{C}$, while $\mathrm{CO}_{2}$ declines continuously. The global reaction approaches completion at above $1000^{\circ} \mathrm{C}$, yielding $\mathrm{Fe}$ and $\mathrm{CO}$. 


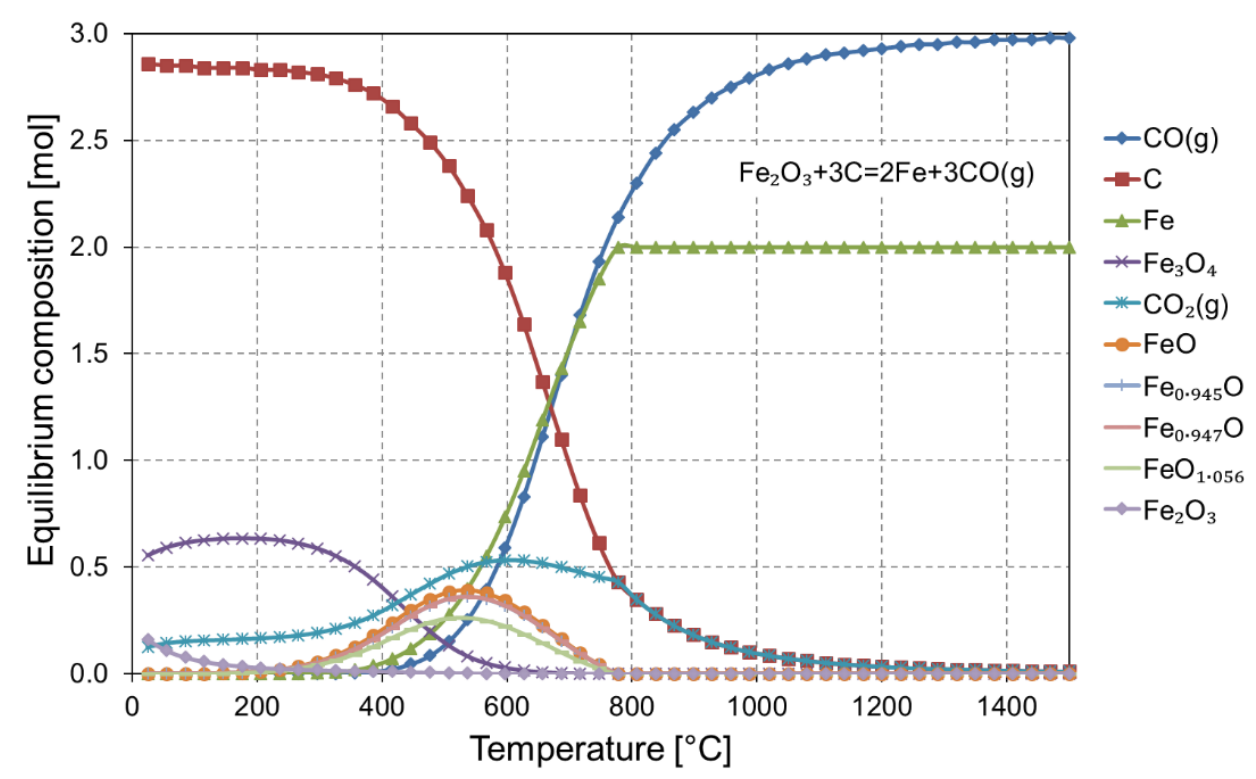

Figure 4. Thermodynamic equilibrium composition of $\mathrm{Fe}_{2} \mathrm{O}_{3}$ carbothermal reduction as a function of temperature at 1 bar.

\subsection{Cerium oxide}

Solar CLRM based on non-stoichiometric cerium oxide is represented as:

Reduction step: $\mathrm{CeO}_{2}+\delta \mathrm{CH}_{4} \rightarrow \mathrm{CeO}_{2-\delta}+\delta \mathrm{CO}+2 \delta \mathrm{H}_{2}$

Oxidation step: $\mathrm{CeO}_{2-\delta}+\delta \mathrm{H}_{2} \mathrm{O} \rightarrow \mathrm{CeO}_{2}+\delta \mathrm{H}_{2}$

The thermodynamic equilibrium composition for the reduction step (Figure 5) shows that $\mathrm{CH}_{4}$ first starts thermally decomposing into both solid carbon and $\mathrm{H}_{2}(\mathrm{~g})$, while the reduction of $\mathrm{CeO}_{2}$ proceeds with the formation of $\mathrm{CeO}_{1.81}$ and $\mathrm{CeO}_{1.78}$. Meanwhile, small amounts of both $\mathrm{H}_{2} \mathrm{O}(\mathrm{g})$ and $\mathrm{CO}_{2}(\mathrm{~g})$ are formed at the beginning of reaction. Subsequently, C deposition starts reacting with oxygen released from ceria resulting in $\mathrm{CO}$ formation at above $500{ }^{\circ} \mathrm{C}$. Non-stoichiometric compounds $\left(\mathrm{CeO}_{1.72}\right.$ and $\mathrm{CeO}_{1.83}$ mainly, and $\mathrm{CeO}_{1.67}$ in negligible amount) are formed as intermediate species, which provide a good representation of the overall reduction mechanism during $\mathrm{Ce}(\mathrm{IV})$ reduction into $\mathrm{Ce}(\mathrm{III})$ species. The reaction 
reaches completion at above $1000{ }^{\circ} \mathrm{C}$, yielding $\mathrm{Ce}_{2} \mathrm{O}_{3}$ and $\mathrm{H}_{2} / \mathrm{CO}$ mixture (with $\mathrm{H}_{2} / \mathrm{CO}$ ratio approaching two).

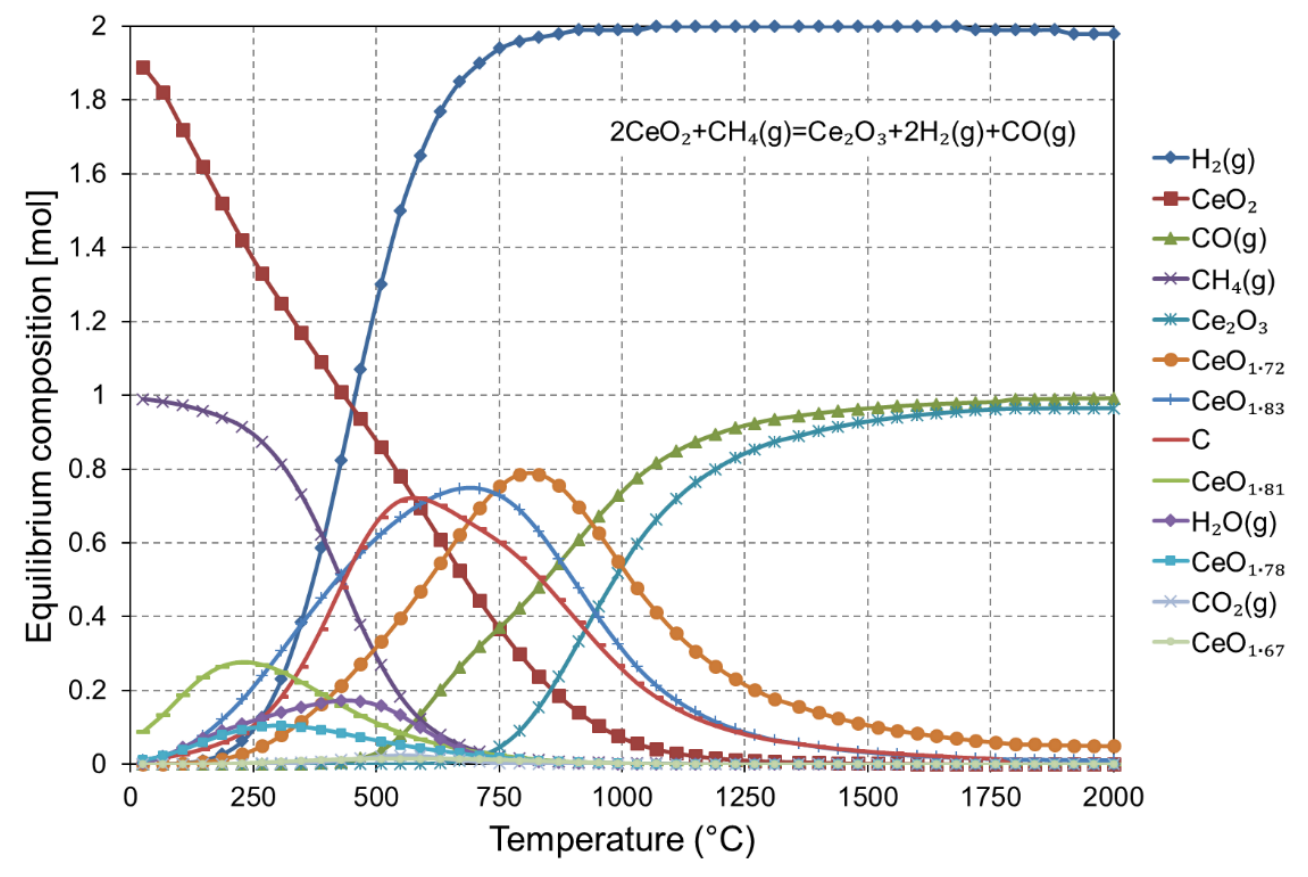

Figure 5. Thermodynamic equilibrium composition of methane reforming over ceria as a function of temperature at 1 bar.

\section{Experimental set up and methods}

The solar reactor concept is schematically showed in Figure 6. ${ }^{[7]}$ The solar reactor consists of a cylindrical metallic cavity receiver with a conical part $\left(60^{\circ}\right.$ angle) at its bottom (volume: 0.299 L and total height: $115 \mathrm{~mm}$ ), wrapped by a $30 \mathrm{~mm}$-thick alumino-silicate insulation layer. The insulated cavity receiver is vertically placed in a water-cooled cylindrical stainlesssteel shell and then closed by an alumina cap with a $20 \mathrm{~mm}$-diameter aperture for the access of concentrated sunlight. A protective graphite plate (2 mm-thick) with a $15 \mathrm{~mm}$-diameter aperture is positioned on top of the alumina cap to protect it. A hemispherical transparent glass window equipped with a small fluorine window is lastly attached to the front flange edge of the reactor shell. A 2-m diameter parabolic mirror with a solar concentration ratio above 10000 suns (peak flux density of $\sim 10.5 \mathrm{MW} / \mathrm{m}^{2}$ at the focal plane for a DNI of 1 


\section{WILEY-VCH}

$\mathrm{kW} / \mathrm{m}^{2}$ ) is employed to concentrate sunlight to the focal point where the reactor aperture is positioned.
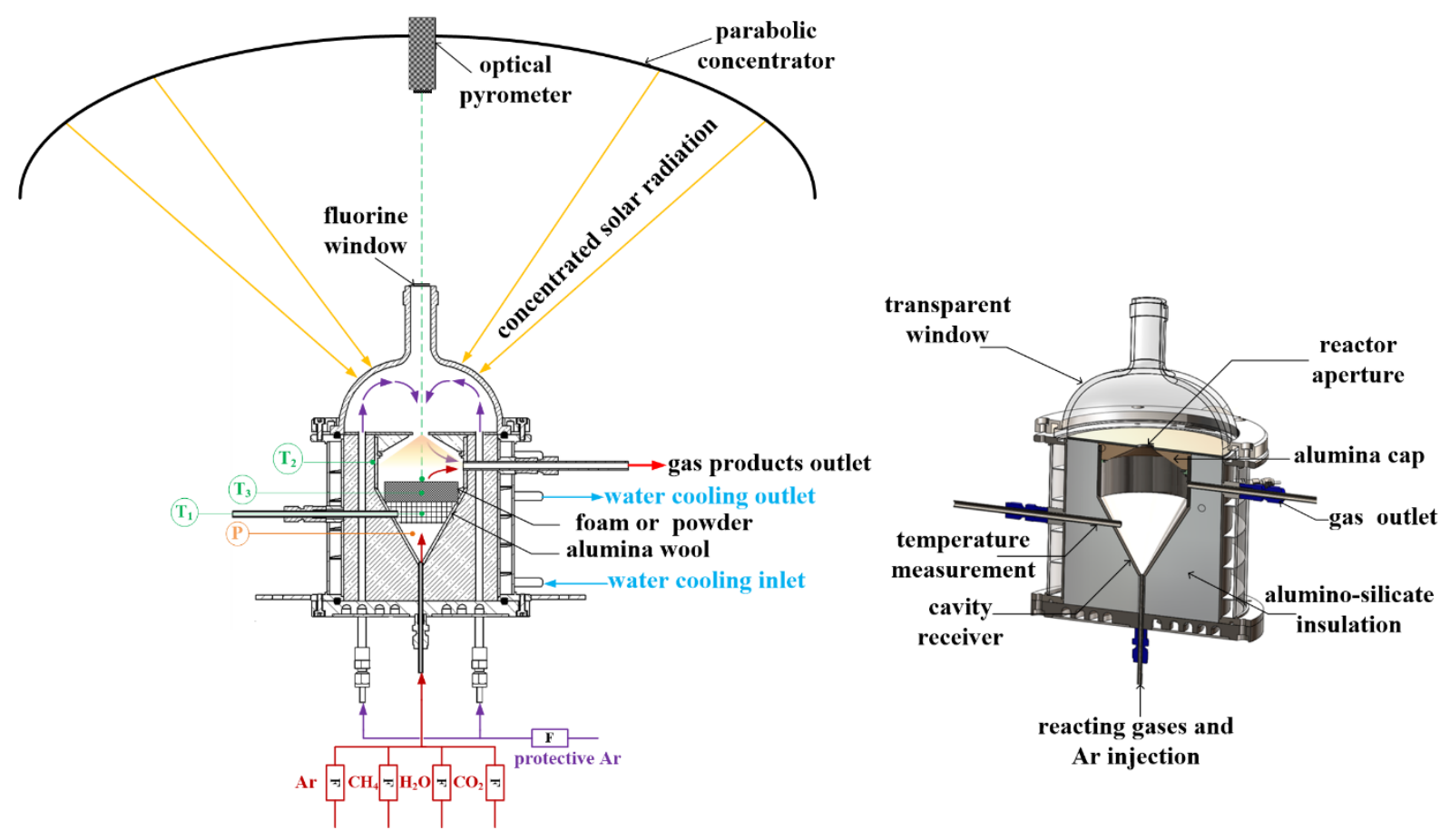

Figure 6. Schematic of the $1.5 \mathrm{~kW}_{\text {th }}$ directly-irradiated solar reactor and external components (left) and 3D cross section of the solar reactor (right).

Three temperatures are measured by B-type thermocouples inside the alumina wool supporting the reactive material $\left(\mathrm{T}_{1}\right)$, at the external cavity wall surface $\left(\mathrm{T}_{2}\right)$, and in the middle of samples $\left(\mathrm{T}_{3}\right)$; and an optical pyrometer (operating at 4.8-5.2 $\mu \mathrm{m}$ in a $\mathrm{H}_{2} \mathrm{O}$ absorption band) also measures the temperature at the uppermost sample surface $\left(\mathrm{T}_{\text {pyrometer }}\right)$ through the fluorine window. In addition, the operating pressure $(\mathrm{P})$ inside the cavity receiver is measured by a pressure transducer. $\mathrm{CH}_{4}$ and $\mathrm{Ar}$ (gases purity of $99.999 \%$ ) flow-rates are controlled by electronic Mass Flow Controllers (MFC, Brooks Instruments model SLA5850S, range $0-5 \mathrm{Nl} / \mathrm{min} \pm 0.2 \%$ of full scale), while liquid water $\left(\mathrm{H}_{2} \mathrm{O}\right)$ flow-rate is also regulated by a MFC (range $0-30 \mathrm{~g} / \mathrm{h} \pm 1 \%$ of full scale). 


\section{WILEY-VCH}

A given amount of cerium or iron oxide is loaded within the cavity receiver directly subjected to concentrated sunlight. The materials preparation is described in Supporting Information (materials synthesis). Two types of materials structures for each oxide (powders and porous foams) were assessed to compare their thermochemical reactivity. Since the objective is to conduct the thermochemical reactions in a solar reactor, efficient solar radiation absorption and high heat and mass transfer rates are necessary to warrant homogeneous material heating and reaction in the whole structure for utilization of the entire reactant mass. Therefore, using reticulated porous foam may be an attractive option for volumetric solar radiative absorption while offering a large available interface for gas species access and solid/gas reactions. Reactive gases $\left(\mathrm{CH}_{4}\right.$ or $\left.\mathrm{H}_{2} \mathrm{O}\right)$ and Ar carrier gas are fed via the single inlet port at the bottom of the cavity receiver. Prior to gas analysis, product gases flow through a gas scrubber composed of both bubbler and gas filtering unit (two micro filters with $0.1 \mu \mathrm{m}$ pore diameter) to remove moisture and entrained solid carbon particles. The gas composition is then analyzed by an on-line syngas analyzer (GEIT 3100 , uncertainty $< \pm 0.1 \%$ of full scale), and all the measured data are recorded by an automated data acquisition system (BECKHOFF). The reactor cavity was initially flushed by Ar and sucked by a venturi pump to eliminate residual air from the system. Ar protective gas $(2.0 \mathrm{Nl} / \mathrm{min})$ was also provided to the window area to prevent the hot gas contact with the transparent window. Subsequently, the reactor was gradually heated by concentrated sunlight to the desired temperature (referred by $\mathrm{T}_{3}$ ) under Ar. The solar power input was regulated by means of shutter opening to stabilize $T_{3}$. Once $T_{3}$ was at steady-state, a $\mathrm{CH}_{4} / \mathrm{Ar}$ gas mixture (50\% $\mathrm{CH}_{4}$ concentration) was delivered to the reaction zone to drive the reduction reaction. After finishing reduction, reflected by $\mathrm{H}_{2}$ and $\mathrm{CO}$ concentrations approaching zero, $\mathrm{CH}_{4}$ flow was stopped and only Ar flow was fed to remove residual $\mathrm{CH}_{4}$. Subsequently, the oxidation was performed by injecting $\mathrm{H}_{2} \mathrm{O}$ at the same temperature (isothermal operation). The $\mathrm{H}_{2} \mathrm{O}$ flow was stopped when $\mathrm{H}_{2}$ evolution ceased. 
The pressure was maintained at $\sim 0.9$ bar $\left(\mathrm{P}_{\mathrm{atm}}=\sim 0.85\right.$ bar at site elevation $1,500 \mathrm{~m}$ above sea level) for both steps.

During partial oxidation of methane with metal oxides, the formation of both $\mathrm{H}_{2} \mathrm{O}$ and $\mathrm{CO}_{2}$ is also possible according to Equation 14:

$4 \mathrm{M}_{\mathrm{x}} \mathrm{O}_{\mathrm{y}}+\delta \mathrm{CH}_{4} \longrightarrow 4 \mathrm{M}_{\mathrm{x}} \mathrm{O}_{\mathrm{y}-\delta}+\delta \mathrm{CO}_{2}+2 \delta \mathrm{H}_{2} \mathrm{O}$

Therefore, oxygen released from the oxide structure is recovered in the forms of $\mathrm{CO}, \mathrm{CO}_{2}$, and $\mathrm{H}_{2} \mathrm{O}$ (twice the amount of $\mathrm{CO}_{2}$ ). The global amount of oxygen released from the oxide structure $\left(\mathrm{n}_{\mathrm{O}, \mathrm{red}}\right)$ is therefore determined by:

$n_{\mathrm{O}, \mathrm{red}}=n_{\mathrm{CO}}+2 n_{\mathrm{CO}_{2}}+n_{\mathrm{H}_{2} \mathrm{O}}$

Where $n_{i}$ are the mole amounts of species $i$.

The replenished amount of oxygen $\left(\mathrm{n}_{\mathrm{O}, \mathrm{ox}}\right)$ during oxidation with $\mathrm{H}_{2} \mathrm{O}$ (Equation 9 and 13) can be calculated from oxygen mass balance (equal to total amount of produced $\mathrm{H}_{2}$ minus amounts produced from carbon gasification with $\mathrm{H}_{2} \mathrm{O}$ according to Equation 10 and 11):

$n_{O, o x}=n_{\mathrm{H}_{2}}-n_{\mathrm{CO}}-2 n_{\mathrm{CO}_{2}}$

Contrary to iron oxide $\left(\mathrm{Fe}_{3} \mathrm{O}_{4}\right.$ cannot be reversibly oxidized with $\mathrm{H}_{2} \mathrm{O}$ to $\left.\mathrm{Fe}_{2} \mathrm{O}_{3}\right)$, the partiallyreduced ceria $\left(\mathrm{CeO}_{2-\delta}\right)$ can be completely re-oxidized to $\mathrm{CeO}_{2}$. The oxygen non-stoichiometry during reduction $\left(\delta_{\text {red }}\right)$ can be defined by:

$\delta_{\text {red }}=\frac{n_{O, \text { red }}}{n_{\mathrm{CeO}_{2}}}$ 
The replenished oxygen $\left(\delta_{\text {ox }}\right)$ during ceria oxidation with $\mathrm{H}_{2} \mathrm{O}$ (Equation 13) can be calculated as follows:

$\delta_{o x}=\frac{n_{O, o x}}{n_{\mathrm{CeO}_{2}}}$

For reduction, the $\mathrm{CH}_{4}$ conversion is defined by:

$X_{\mathrm{CH}_{4}}=1-\frac{\dot{m}_{\text {unreacted } \mathrm{CH}_{4}}}{\dot{m}_{\mathrm{CH}_{4}}}$

Where $\dot{m}_{\text {unreacted } \mathrm{CH}_{4}}$ is the mass flow rate of unreacted $\mathrm{CH}_{4}$, and $\dot{m}_{\mathrm{CH}_{4}}$ is the mass flow rate of injected $\mathrm{CH}_{4}$.

Moreover, the quality of products is assessed from the selectivity of $\mathrm{H}_{2}\left(\mathrm{~S}_{\mathrm{H} 2}\right)$ and $\mathrm{CO}\left(\mathrm{S}_{\mathrm{CO}}\right)$ towards syngas products:

$S_{H_{2}}=\frac{n_{H_{2}}}{n_{H_{2}}+n_{H_{2} O}}$

$S_{C O}=\frac{n_{C O}}{n_{C O}+n_{\mathrm{CO}_{2}}}$

Where $n_{\mathrm{H}_{2}}$ and $n_{\mathrm{CO}}$ are the total moles of produced $\mathrm{H}_{2}$ and $\mathrm{CO}$ during oxidation and reduction steps, $n_{\mathrm{H}_{2} \mathrm{O}}$ and $n_{\mathrm{CO}_{2}}$ the moles of produced $\mathrm{H}_{2} \mathrm{O}$ (equal to twice the mole of $\mathrm{CO}_{2}$ ) and $\mathrm{CO}_{2}$ during reduction step.

All the operating conditions and experimental results for 29 cycles performed isothermally with iron and cerium oxides in the solar reactor are listed in Supporting Information (Table S1).

\section{Results and discussion}

\subsection{Methane reforming over iron oxide}




\section{WILEY-VCH}

Pure raw $\mathrm{Fe}_{2} \mathrm{O}_{3}$ powder (total mass: $20.52 \mathrm{~g}$ ) (Figure S3a) was employed as an oxygen carrier material for the solar CLRM test. Experiments were conducted with 4 cycles at 950$1100{ }^{\circ} \mathrm{C}$. Both $\mathrm{CH}_{4}$ and Ar carrier gas flow-rates were injected at $0.2 \mathrm{Nl} / \mathrm{min}$ for reduction step (50\% inlet $\mathrm{CH}_{4}$ mole fraction), while $\mathrm{H}_{2} \mathrm{O}$ flow-rate was fed at $200 \mathrm{mg} / \mathrm{min}$ along with Ar carrier gas $(0.2 \mathrm{Nl} / \mathrm{min})$ for subsequent oxidation step, yielding $55 \%$ steam mole fraction at inlet.

The transient syngas production rates along with nominal reactor temperature $\left(\mathrm{T}_{3}\right)$ during iron oxide powder reduction with methane and during reduced iron oxidation with $\mathrm{H}_{2} \mathrm{O}$ for four consecutive cycles are plotted for the respective temperatures of 1000, 1100, 950, and $1000{ }^{\circ} \mathrm{C}$ (Figure S4). Note that the outlet flow rate of each gas specie $\left(\mathrm{F}_{\mathrm{i}}\right)$ was calculated from their measured mole fraction $\left(\mathrm{y}_{\mathrm{i}}\right)$ and the known total inlet flow rate of $\operatorname{Ar}\left(\mathrm{F}_{\mathrm{Ar}}\right)$ : $\left(F_{i}=F_{A r} \cdot y_{i} / y_{A r}\right)$. During reduction step, the maximum $\mathrm{CO}_{2}$ production rate $(0.09 \mathrm{Nl} / \mathrm{min})$ was noticed at the initial stage of the reaction at cycle \#1 (Figure S4a); moreover, its amount was higher than those of $\mathrm{CO}$ and $\mathrm{H}_{2}$. Actually, $\mathrm{H}_{2} \mathrm{O}$ was also formed simultaneously in accordance with thermodynamic analysis; however, it cannot be detected from gas analysis. The $\mathrm{CO}_{2}$ production rate was observed again at cycle \#2 (but it was lower than cycle \#1) when increasing the temperature to $1100{ }^{\circ} \mathrm{C}$ (Figure S4c), and after initial stage its trend remained stable along with $\mathrm{H}_{2}$ and $\mathrm{CO}$ production rates. The peak $\mathrm{H}_{2}$ and $\mathrm{CO}$ production rates $(0.07$ and $0.04 \mathrm{Nl} / \mathrm{min})$ were found at the highest reduction temperature $\left(1100{ }^{\circ} \mathrm{C}\right.$, Figure $\left.\mathrm{S} 4 \mathrm{c}\right)$. After cycle \#2, the syngas $\left(\mathrm{H}_{2}, \mathrm{CO}\right.$, and $\left.\mathrm{CO}_{2}\right)$ production rates during reduction were found in negligible amounts (Figure S4e and S4g). During oxidation step, the peak of $\mathrm{H}_{2}$ production rate $(0.077 \mathrm{Nl} / \mathrm{min})$ was also found at the same temperature $\left(1100{ }^{\circ} \mathrm{C}\right.$, Figure $\left.\mathrm{S} 4 \mathrm{~d}\right)$, followed by $1000{ }^{\circ} \mathrm{C}\left(0.052 \mathrm{Nl} / \mathrm{min}\right.$, Figure S4b) and $950^{\circ} \mathrm{C}(0.035 \mathrm{Nl} / \mathrm{min}$, Figure $\mathrm{S} 4 \mathrm{f})$, while extremely small evolution of $\mathrm{CO}$ and $\mathrm{CO}_{2}$ was noticed for any oxidation temperatures. Thus, the negligible impact of carbon deposition from methane cracking was demonstrated for the CLRM over iron oxide. Noticeably, the methane reforming over iron oxide required long 


\section{WILEY-VCH}

duration to reach completion (because of strong oxide sintering during reduction and low available specific surface area) and strongly depended on the reduction temperature as evidenced in Figure S4c (the required reduction temperature was higher than for $\mathrm{CH}_{4}$ reforming over ceria (see next section)). First, the reduction of fresh $\mathrm{Fe}_{2} \mathrm{O}_{3}$ to $\mathrm{Fe}_{3} \mathrm{O}_{4}$ in cycle $\# 1$ resulted in a large amount of oxygen released $\left(\mathrm{n}_{\mathrm{O}, \mathrm{red}}=0.095\right.$ vs. $\mathrm{n}_{\mathrm{O}, \mathrm{ox}}=0.012$, Figure 7$)$ in the form of $\mathrm{CO}_{2}$. Then, during the oxidation step of cycle \#1, re-oxidation to $\mathrm{Fe}_{2} \mathrm{O}_{3}$ is not possible (only $\mathrm{Fe}_{3} \mathrm{O}_{4}$ can be formed, Equation 9) ${ }^{[38]}$, as evidenced by $\mathrm{n}_{\mathrm{O}, \mathrm{ox}}$ much lower than $\mathrm{n}_{\mathrm{O} \text {,red }}$ (Figure 7). The material was deactivated after cycle $\# 2$ because operation at $1100{ }^{\circ} \mathrm{C}$ resulted in strong sintering despite achieving high reduction rate, as reflected by increased $\mathrm{CO}$ and $\mathrm{H}_{2}$ production rates and maximum $\mathrm{X}_{\mathrm{CH}_{4}}(33.8 \%)$.

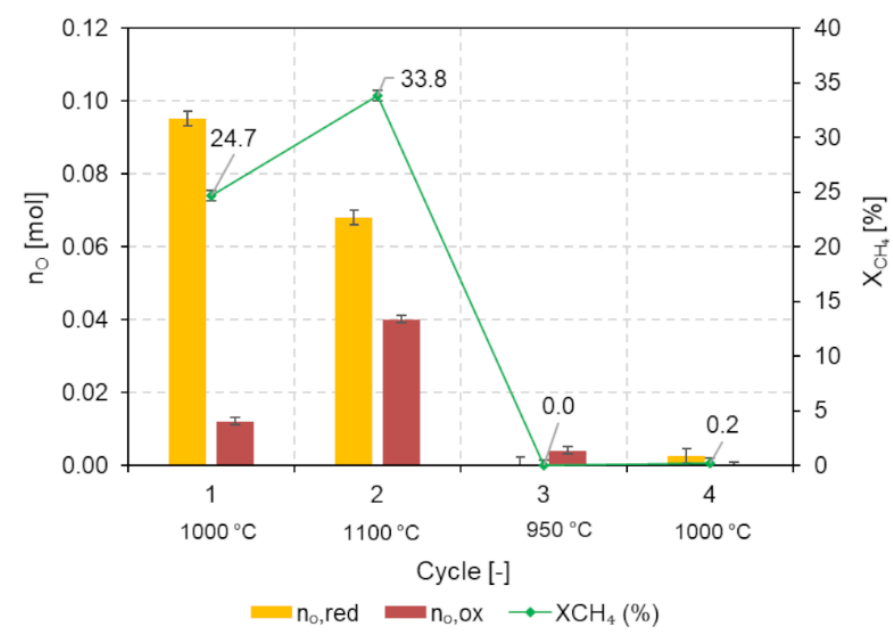

Figure 7. Comparison of $\mathrm{n}_{\mathrm{O}, \text { red }}$ and $\mathrm{n}_{\mathrm{O}, \mathrm{ox}}$ along with $\mathrm{CH}_{4}$ conversion during four consecutive redox cycles with iron oxide powder performed at $950-1100{ }^{\circ} \mathrm{C}$.

Figure $\mathbf{8}$ shows the syngas yields quantified from the integration of the measured syngas production rates (Figure S4) during reduction and oxidation steps. As expected, the highest $\mathrm{CO}_{2}$ yield $\left(1.06 \mathrm{mmol} / \mathrm{g}_{\mathrm{Fe}_{2} \mathrm{O}_{3}}\right)$ was found in cycle \#1, followed by cycle \#2 $\left(0.5 \mathrm{mmol} / \mathrm{g}_{\mathrm{Fe}_{2} \mathrm{O}_{3}}\right)$ while the maximum total syngas yield $\left(4.0 \mathrm{mmol} / \mathrm{g}_{\mathrm{Fe}_{2} \mathrm{O}_{3}}\right)$ was produced in cycle \#2 (Figure. 8a), and no effect of $\mathrm{CH}_{4}$ cracking reaction (Equation 7) was observed as evidenced by a zero 


\section{WILEY-VCH}

amount of $\mathrm{H}_{2}\left(\mathrm{CH}_{4}\right.$ cracking $)$. Note that the amount of $\mathrm{H}_{2}\left(\mathrm{CH}_{4}\right.$ cracking) was quantified by the total $\mathrm{H}_{2}$ yield measured by gas analysis minus the $\mathrm{H}_{2}$ yield produced by the main reaction of iron oxide with methane (Equation 6), which is equivalent to twice the quantity of produced CO. In addition, no syngas production was observed in cycle \#3 (the reduction reaction was negligible as evidenced by $\mathrm{X}_{\mathrm{CH}_{4}}=0 \%$, Figure 7), and a negligible syngas yield was found in cycle \#4. These are because of a dramatic decrease in available surface area resulting from high sintering/coarsening and densification of the new-formed metallic iron particles after being reduced at high temperature $\left(1100^{\circ} \mathrm{C}\right.$, cycle \#2), thereby leading to material deactivation and negligible re-oxidation. For these reasons, its powder structure cannot be backed to the initial stage despite passing re-oxidation step, thus adversely influencing the CLRM process in cycles \#3 and \#4 and thereby leading to negligible amounts of syngas produced. This was confirmed by the high sintering of iron powder structure observed after 4 cycles (Figure S5).

Figure $8 \mathrm{~b}$ shows that most of the produced syngas yields during oxidation step was enticing from $\mathrm{H}_{2}$ associated with the main reaction (Equation 9), and the maximum total syngas yield ( $2.15 \mathrm{mmol} / \mathrm{g}_{\mathrm{Fe}_{2} \mathrm{O}_{3}}$ ) was found in cycle \#2 in accordance with high syngas production rate in the reduction step. Moreover, negligible $\mathrm{CO}\left(\mathrm{C}+\mathrm{H}_{2} \mathrm{O}\right), \mathrm{CO}_{2}\left(\mathrm{C}+2 \mathrm{H}_{2} \mathrm{O}\right), \mathrm{H}_{2}\left(\mathrm{C}+\mathrm{H}_{2} \mathrm{O}\right)$, and $\mathrm{H}_{2}$ $\left(\mathrm{C}+2 \mathrm{H}_{2} \mathrm{O}\right)$ yields formed by side reactions (Equation 10 and 11) were noticed, confirming that methane cracking reaction over iron oxide is not favored at $950-1100{ }^{\circ} \mathrm{C}$ (note that the $\mathrm{H}_{2}$ $\left(\mathrm{C}+\mathrm{H}_{2} \mathrm{O}\right)$ yield is equal to the $\mathrm{CO}$ yield measured by gas analysis (Equation 10), while the $\mathrm{H}_{2}$ $\left(\mathrm{C}+2 \mathrm{H}_{2} \mathrm{O}\right)$ yield is equal to twice the $\mathrm{CO}_{2}$ yield measured by gas analysis (Equation 11)). In addition, the $\mathrm{H}_{2}$ (Equation 20) and $\mathrm{CO}$ (Equation 21) selectivity (Table S1) rose sharply during cycling (e.g. from 28.6 and $34.8 \%$ at cycle \#1 to 59.2 and $96.6 \%$ at cycle \#3, respectively), because of the drop of $\mathrm{H}_{2} \mathrm{O}$ and $\mathrm{CO}_{2}$ yields. The reduced iron oxide after reduction step in cycle \#4 was not re-oxidized, as it was kept for X-ray diffraction (XRD) analysis to characterize its phase composition (Figure S6). Phase identification shows the 
presence of mainly $\mathrm{FeO}$, followed by traces of $\mathrm{Fe}_{3} \mathrm{O}_{4}$ and $\mathrm{Fe}$. Thus, most of the iron oxide powder did not completely reduce to Fe despite already passing the reduction step with methane, thereby confirming material deactivation.
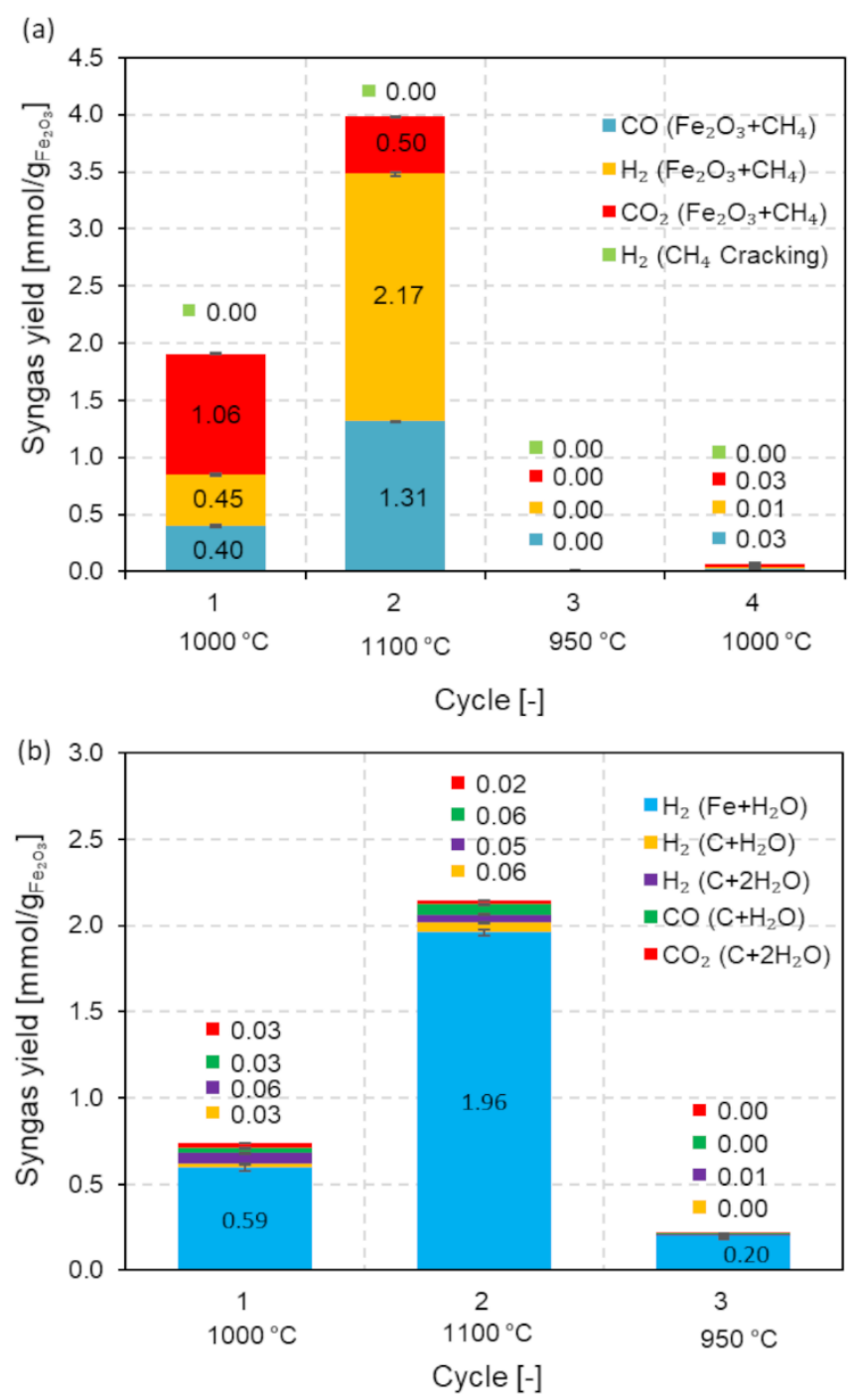

Figure 8. Syngas yields for (a) iron oxide powder reduction with $\mathrm{CH}_{4}$ and (b) oxidation with $\mathrm{H}_{2} \mathrm{O}$ during isothermal cycles at temperatures in the range $950-1100{ }^{\circ} \mathrm{C}$.

In order to confirm experimental repeatability and compare the results, another iron oxide structure (reticulated porous foam, total $\mathrm{Fe}_{2} \mathrm{O}_{3}$ mass: $13.91 \mathrm{~g}$ ) was prepared (Figure S3b) via a replication technique ${ }^{[7]}$ and subsequently employed as an oxygen carrier material for the solar-driven CLRM. Experiments were conducted with seven consecutive cycles at different reduction temperatures in the range $1000-1150{ }^{\circ} \mathrm{C}$, while the flow rates of $\mathrm{CH}_{4}, \mathrm{H}_{2} \mathrm{O}$, and $\mathrm{Ar}$ 


\section{WILEY-VCH}

were the same as the previous tests with iron oxide powder $\left(\mathrm{CH}_{4}: 0.2 \mathrm{Nl} / \mathrm{min}, \mathrm{H}_{2} \mathrm{O}: 200\right.$ $\mathrm{mg} / \mathrm{min}$, and total Ar: $2.2 \mathrm{Nl} / \mathrm{min})$.

During reduction step, the peak rates of $\mathrm{CO}_{2}$ production decreased, while the peak of $\mathrm{H}_{2}$ and CO remained stable with cycles repetition from cycle \#1 to cycle $\# 3$ at $1000^{\circ} \mathrm{C}$ (Figure S7). For example, the peak rates of $\mathrm{CO}_{2}, \mathrm{H}_{2}$, and $\mathrm{CO}$ production are $0.11,0.02$, and $0.02 \mathrm{Nl} / \mathrm{min}$ at cycle \#1 compared to $0.01,0.02$, and $0.02 \mathrm{Nl} / \mathrm{min}$ at cycle \#3. During oxidation step, the peak rate of $\mathrm{H}_{2}$ production seemed to decrease slightly $(0.07 \mathrm{Nl} / \mathrm{min}$ at cycle \#1 compared to 0.06 $\mathrm{Nl} /$ min at cycle \#3) while no $\mathrm{CO}$ and $\mathrm{CO}_{2}$ production was evidenced. $\mathrm{X}_{\mathrm{CH}_{4}}$ decreased dramatically from $24.9 \%$ at cycle \#1 to $3.7 \%$ at cycle \#3 (Figure 9) arising from the sharp decline in oxygen release during reduction steps of cycles \#2 $\left(\mathrm{n}_{\mathrm{O}, \mathrm{red}}=0.012\right)$ and \#3 $\left(\mathrm{n}_{\mathrm{O}, \text { red }}=0.009\right)$ compared to cycle $\# 1\left(\mathrm{n}_{\mathrm{O}, \text { red }}=0.059\right)$, caused by non-reversible $\mathrm{Fe}_{2} \mathrm{O}_{3}$ reduction to $\mathrm{Fe}_{3} \mathrm{O}_{4}$, in agreement with thermodynamic analysis (Figure 3).

Similar to previous tests with iron oxide powder, the kinetics of methane reforming with iron oxide porous foam were too slow at $1000{ }^{\circ} \mathrm{C}$ to allow reaching completion $\left(\mathrm{CH}_{4}\right.$ injection was therefore stopped before $\mathrm{H}_{2}$ and $\mathrm{CO}$ approached zero (cycles \#1-3, Figure S7a, S7c and S7e)). The reaction rates were enhanced when increasing the temperature to $1050{ }^{\circ} \mathrm{C}$ according to Figure S7g and S7h. For example, the peak rates of $\mathrm{H}_{2}$ and $\mathrm{CO}$ production were 0.09 and 0.05 $\mathrm{Nl} /$ min during reduction step (Figure $\mathrm{S} 7 \mathrm{~g}$ ), while the peak rate of $\mathrm{H}_{2}$ production was 0.11 $\mathrm{Nl} /$ min during oxidation step at $1050{ }^{\circ} \mathrm{C}$, and negligible $\mathrm{CO}$ and $\mathrm{CO}_{2}$ production rates were observed (Figure S7h), confirming the absence of carbon formation during reduction step. The temperature was increased to $1150{ }^{\circ} \mathrm{C}$ in cycle \#5 (Figures S7i and S7j) to further hasten the kinetic rate of reduction. As a result, the syngas evolution profile (Figure S7i) increased considerably; however, the effect of methane cracking reaction was detected as reflected by the peak of $\mathrm{H}_{2}$ after 18 min with the maximum $\mathrm{X}_{\mathrm{CH}_{4}}(68.3 \%$, Figure 9) while $\mathrm{CO}$ approached zero (thus indicating the end of iron oxide reduction). Note that the formed carbon can also act as reducing agent $\left(\mathrm{Fe}_{3} \mathrm{O}_{4}\right.$ reduction) according to thermodynamics (Figure 4 and $\mathrm{S} 2$ ), and 


\section{WILEY-VCH}

the cracking reaction may also be catalyzed by the newly formed metallic iron. ${ }^{[27]}$ During oxidation with $\mathrm{H}_{2} \mathrm{O}$, both a sharp growth in $\mathrm{CO}$ (consistent with the $\mathrm{H}_{2}$ evolution profile) and a significant increase in $\mathrm{CO}_{2}$ were noticed (Figure $\mathrm{S} 7 \mathrm{j}$ ), arising from the reaction of deposited $\mathrm{C}$ with $\mathrm{H}_{2} \mathrm{O}$ and confirming that $1150{ }^{\circ} \mathrm{C}$ is favorable for $\mathrm{CH}_{4}$ cracking reaction in this cycle. When the rate of oxide reduction is lower than the rate of methane decomposition, chemisorbed carbon may accumulate at the surface. This occurs when the rate of bulk lattice oxygen diffusion to the surface becomes lower than the $\mathrm{CH}_{4}$ supply rate. In other words, when a lack of oxygen at the surface occurs, carbon deposition is fastened, which is increasingly favored as oxygen is being depleted during the iron oxide reduction progress.

The temperature was then decreased by $50{ }^{\circ} \mathrm{C}$ in cycle \#6 to alleviate the adverse impact of $\mathrm{CH}_{4}$ cracking reaction; nevertheless, the resulting syngas associated with $\mathrm{CH}_{4}$ decomposition remained high as reflected by a stable $\mathrm{H}_{2}$ evolution profile in the reduction step even if $\mathrm{CO}$ approached zero (Figure S7k) and a steep increase of the $\mathrm{CO}$ along with $\mathrm{H}_{2}$ in the oxidation step (Figure S71). This may possibly be also due to the carbon accumulation from the previous cycle.

The cycling experiment was completed with the reduction step performed at $1000{ }^{\circ} \mathrm{C}$ (cycle \#7, Figure $\mathrm{S} 7 \mathrm{~m}$ ). It was found that no $\mathrm{CO}_{2}$ production was evolved; in contrast, the peak $\mathrm{H}_{2}$ production rate was higher $(0.06 \mathrm{Nl} / \mathrm{min})$ while the peak $\mathrm{CO}$ production rate remained the same $(0.02 \mathrm{Nl} / \mathrm{min})$ as compared to those obtained from cycles \#1-3. This suggests that the amount of excess available oxygen at the iron oxide surface was restrained in this last cycle, explaining the preferential formation of $\mathrm{CO}$ rather than $\mathrm{CO}_{2}$ (and $\mathrm{H}_{2} \mathrm{O}$ ). Indeed, $\mathrm{CO}_{2}$ and $\mathrm{H}_{2} \mathrm{O}$ formation is favored when an excess amount of surface oxygen is available, thus occurring during the first cycle because the pristine oxide is $\mathrm{Fe}_{2} \mathrm{O}_{3}$. In the subsequent cycles, the participating oxide during reduction is either $\mathrm{FeO}$ or $\mathrm{Fe}_{3} \mathrm{O}_{4}$ (because re-oxidation to $\mathrm{Fe}_{2} \mathrm{O}_{3}$ is not thermodynamically possible when using $\mathrm{H}_{2} \mathrm{O}$ as oxidant) with less available oxygen for 
the reduction step. Moreover, selectivity increased from $23.2 \%$ to $99.7 \%\left(\mathrm{H}_{2}\right)$ and $33.5 \%$ to 99.9\% (CO), in agreement with the decline in $\mathrm{CO}_{2}$ and $\mathrm{H}_{2} \mathrm{O}$ formation during cycling.

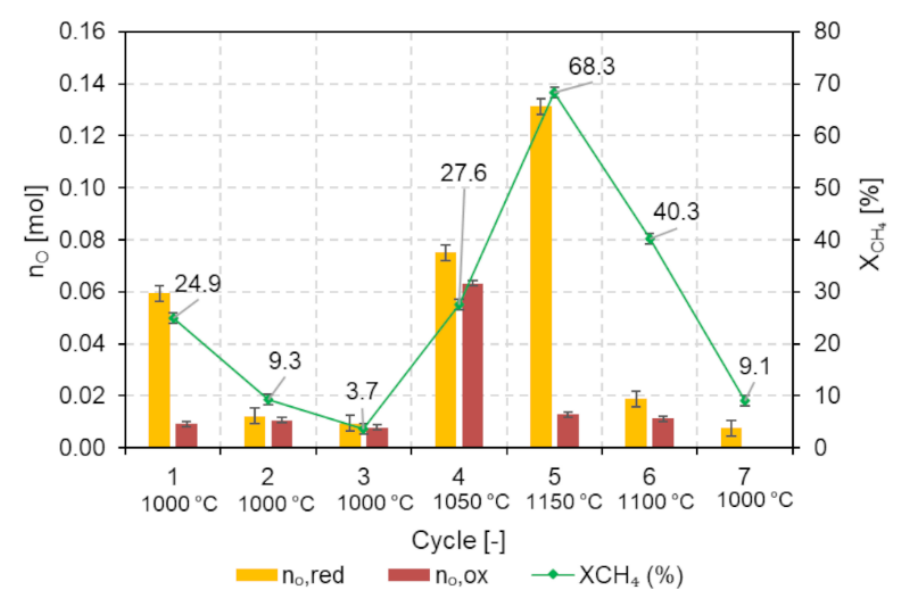

Figure 9. Comparison of $\mathrm{n}_{\mathrm{O}, \text { red }}$ and $\mathrm{n}_{\mathrm{O}, \mathrm{ox}}$ along with $\mathrm{CH}_{4}$ conversion during seven consecutive redox cycles with iron oxide foam performed at $1000-1150{ }^{\circ} \mathrm{C}$.

Once again, the time integration of the measured syngas production rates in Figure S7 during reduction and oxidation steps was used to calculate the syngas yields according to Figure $\mathbf{1 0 .}$ Note that the reduced iron after reduction in the last cycle (cycle \#7) was not re-oxidized, as it was kept for analyzing its phase composition via XRD. Therefore, no syngas yield during oxidation at cycle \#7 was presented.

During reduction step (Figure 10a), as expected a large amount of $\mathrm{CO}_{2}$ was observed during the first reduction $\left(1.00 \mathrm{mmol} / \mathrm{g}_{\mathrm{Fe}_{2} \mathrm{O}_{3}}\right)$ arising from $\mathrm{Fe}_{2} \mathrm{O}_{3}$ reduction to $\mathrm{Fe}_{3} \mathrm{O}_{4}(0.059$ mole of oxygen released, Figure 9), and total syngas yield decreased with cycles repetition (cycles \#13). The syngas yields (especially $\mathrm{H}_{2}$ and $\mathrm{CO}$ ) grew with increasing reduction temperature (cycles \#4-6), thereby confirming that the partial oxidation of $\mathrm{CH}_{4}$ over iron oxide strongly depends on the reduction temperature, and temperatures higher than $1000{ }^{\circ} \mathrm{C}$ were required to favor reactions. However, a remarkable amount of $\mathrm{H}_{2}$ associated with $\mathrm{CH}_{4}$ cracking (3.01$\left.5.57 \mathrm{mmol} / \mathrm{g}_{\mathrm{Fe}_{2} \mathrm{O}_{3}}\right)$ was inherently measured at cycles \#5-6 because of higher reduction 


\section{WILEY-VCH}

temperatures $\left(1100-1150{ }^{\circ} \mathrm{C}\right)$. Noticeably, $\mathrm{CO}_{2}$ yield decreased with cycles repetition (except in cycle \#5 at which the amount of $\mathrm{CO}_{2}$ was higher than that obtained from cycle \#1 as a result of the exacerbated temperature effect at $1150{ }^{\circ} \mathrm{C}$ ), and it was not observed during the last cycle (cycle \#7). This is because a large amount of the oxygen contained in the iron oxide lattice structure was released during the previous cycles favoring $\mathrm{CO}_{2}$ formation. In fact, $\mathrm{Fe}_{3} \mathrm{O}_{4}$ reduction takes place into two stages: first the reduction from $\mathrm{Fe}_{3} \mathrm{O}_{4}$ to $\mathrm{FeO}$ (Equation 4) and then $\mathrm{FeO}$ to $\mathrm{Fe}$ (Equation 5). The first stage is faster than the second one presumably as a result of produced $\mathrm{H}_{2}$ that reacts with $\mathrm{Fe}_{3} \mathrm{O}_{4}$ (Figure 2) but not with $\mathrm{FeO}{ }^{\left[{ }^{[2]}\right.}$ The slower second reaction stage is caused by the material surface reduction resulting from sintering. ${ }^{[27]}$ These variations may explain the decrease of $\mathrm{CO}_{2}$ with cycles repetition (as evidenced in cycles \#1-7) since the iron oxide structure does not completely return to the initial state despite passing the oxidation step (as proved by $\mathrm{n}_{\mathrm{O}, \mathrm{ox}}$ values always lower than $\mathrm{n}_{\mathrm{O} \text {,red }}$, Figure 9), thereby leading to lower available oxygen for the subsequent reduction reaction. During oxidation step (Figure 10b), most of the produced syngas yield at cycles \#1-4 was ascribed to the production of $\mathrm{H}_{2}$ formed by Equation 9. The $\mathrm{CO}\left(\mathrm{C}+\mathrm{H}_{2} \mathrm{O}\right), \mathrm{CO}_{2}\left(\mathrm{C}+2 \mathrm{H}_{2} \mathrm{O}\right), \mathrm{H}_{2}$ $\left(\mathrm{C}+\mathrm{H}_{2} \mathrm{O}\right)$, and $\mathrm{H}_{2}\left(\mathrm{C}+2 \mathrm{H}_{2} \mathrm{O}\right)$ yields formed by side reactions (Equation 10 and 11) were negligible, implying negligible amount of carbon deposition. In contrast, they were found in significant amounts in cycles \#5-6, suggesting important impact of carbon deposition on syngas yields at $1100-1150{ }^{\circ} \mathrm{C}$. Likewise, the reduced iron oxide composition after reduction in cycle \#7 was characterized by XRD. Its phase identification is presented in Figure S8. The material is mainly composed of $\mathrm{Fe}$, followed by traces of $\mathrm{FeO}$, in agreement with the hard structure of iron in Figure S9b. Most of the iron oxide foam was converted to metallic Fe. It can be assumed that the iron oxide porous foam structure might be lastingly converted to metallic iron coarsened structure after being reduced at $1150{ }^{\circ} \mathrm{C}($ cycle \#5), and that the process is not reversible due to extremely high sintering entailing low re-oxidation ability, as observed in Figure S9b. This assumption can be evidenced by a sharp drop of $\mathrm{H}_{2}\left(\mathrm{Fe}+\mathrm{H}_{2} \mathrm{O}\right)$ 


\section{WILEY-VCH}

yield associated with the oxidation reaction in cycles \#5-6 (ranging between 0.80-0.92

$\mathrm{mmol} / \mathrm{g}_{\mathrm{Fe}_{2} \mathrm{O}}$, Figure $\left.10 \mathrm{~b}\right)$ with extremely low oxygen uptake (0.013 mole for cycle \#5 and 0.011 mole for cycle \#6, Figure 9).
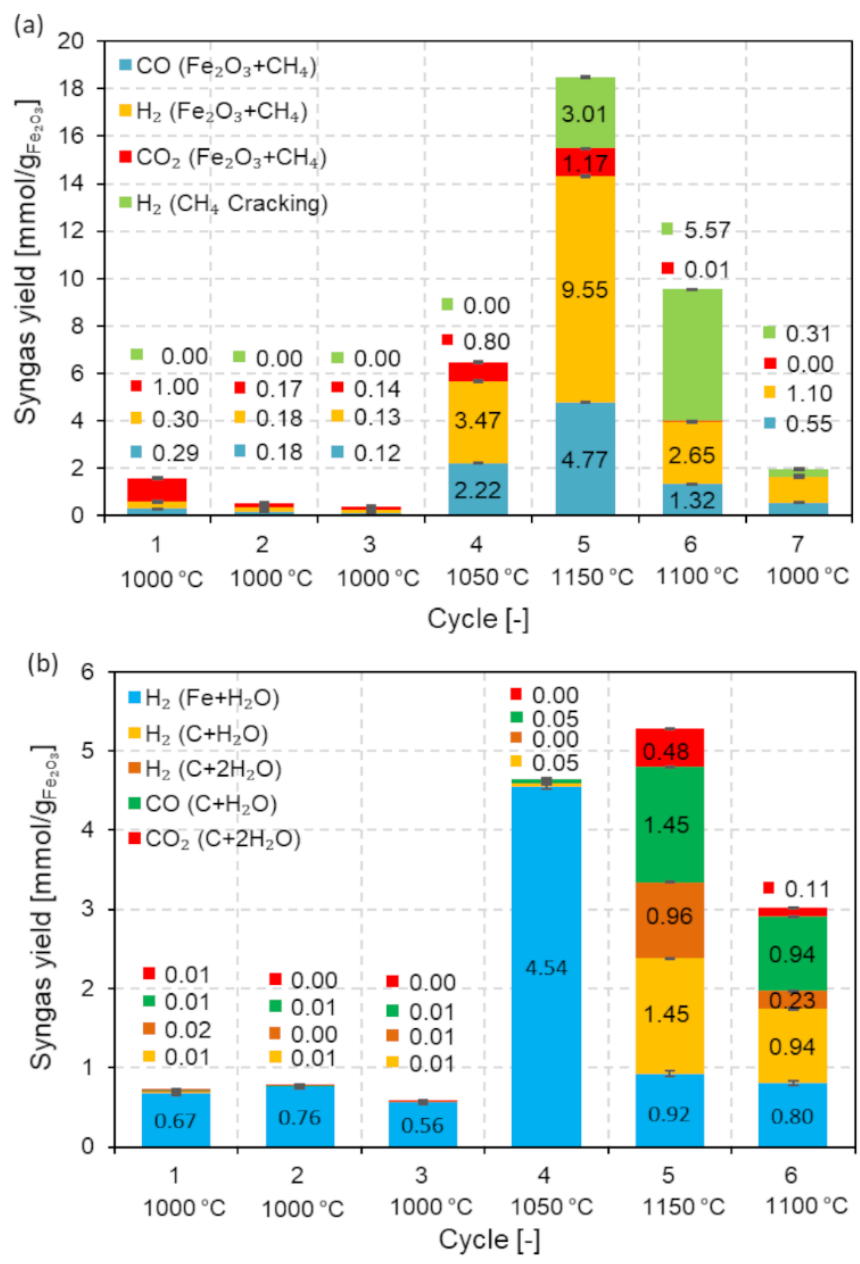

Figure 10. Syngas yields for (a) iron oxide reticulated porous foam reduction with $\mathrm{CH}_{4}$ and (b) oxidation with $\mathrm{H}_{2} \mathrm{O}$ cycled isothermally at temperatures in the range $1000-1150{ }^{\circ} \mathrm{C}$.

In conclusion, the CLRM over both iron oxide powder and foam dramatically suffers from morphological instability (high sintering), slow reaction kinetics, and unfavorable oxidation because of strong material coarsening and densification, thus strongly altering the oxygen exchange reversibility. Then, the oxygen uptake during oxidation is always lower than the oxygen released during reduction because of low material thermal stability. For these reasons, 


\section{WILEY-VCH}

iron oxide is not suitable for CLRM process and would require stabilization for hightemperature processing (e.g. using inert ceramic support for improving material stability). Alternatively, iron oxide reduction using $\mathrm{CH}_{4}$ is suitable for producing both metallic iron and syngas in a solar metallurgical process.

\subsection{Methane reforming over cerium oxide}

In order to compare the performance of oxygen carrier materials for CLRM, nonstoichiometric ceria was experimentally investigated. Pure ceria powder (total mass: 17.01 $\mathrm{g}$, Figure S3c) was employed during six consecutive cycles at a constant temperature of $1000{ }^{\circ} \mathrm{C}$. The same $\mathrm{CH}_{4} / \mathrm{Ar}$ and $\mathrm{H}_{2} \mathrm{O} / \mathrm{Ar}$ gas mixtures were alternately delivered to carry out the reduction and oxidation reactions $\left(\mathrm{CH}_{4}: 0.2 \mathrm{Nl} / \mathrm{min}, \mathrm{H}_{2} \mathrm{O}: 200 \mathrm{mg} / \mathrm{min}\right.$, and $\mathrm{Ar}: 0.2$ $\mathrm{Nl} / \mathrm{min})$.

Figure 11 shows syngas yields quantified from the integration of the measured syngas production rates for six reduction and oxidation cycles. According to Figure 11a, the $\mathrm{H}_{2}$ $\left(\mathrm{CeO}_{2}+\mathrm{CH}_{4}\right), \mathrm{CO}$, and $\mathrm{CO}_{2}$ yields remained quite constant over the entire cycling (in the range 3.39-3.55 mmol $/ \mathrm{g}_{\mathrm{CeO} 2}$ for $\mathrm{H}_{2}, 1.69-1.77 \mathrm{mmol} / \mathrm{g}_{\mathrm{CeO} 2}$ for $\mathrm{CO}$, and $0.05 \mathrm{mmol} / \mathrm{g}_{\mathrm{CeO} 2}$ for $\mathrm{CO}_{2}$ ). The total syngas yield was thus stable (in the range $5.77-6.53 \mathrm{mmol} / \mathrm{g}_{\mathrm{CeO} 2}$ ), in turn leading to stable patterns in $\delta_{\text {red }}(0.32-0.36), \mathrm{X}_{\mathrm{CH}_{4}}(40.8-44.3 \%$, Figure 12), and selectivity (97.1-97.5\% for $\mathrm{H}_{2}$ and 98.5-98.6\% for CO, Table S1) and demonstrating ceria cycling stability. The $\mathrm{H}_{2}\left(\mathrm{CH}_{4}\right.$ cracking $)$ yield fluctuated slightly in the range $0.64-1.16 \mathrm{mmol} / \mathrm{g}_{\mathrm{CeO} 2}$ because of variation in the required $\mathrm{CH}_{4}$ injection duration to reach ceria reduction completion in each cycle. This points out that increasing $\mathrm{CH}_{4}$ injection duration favors the $\mathrm{H}_{2}$ yield associated with $\mathrm{CH}_{4}$ cracking.

Similarly, a stable pattern in the $\mathrm{H}_{2}\left(\mathrm{CeO}_{2-\delta}+\mathrm{H}_{2} \mathrm{O}\right)$ yield, produced during ceria oxidation (Equation 13) was observed (1.94-2.05 mmol/g $\mathrm{g}_{\mathrm{CeO} 2}$, Figure 11b). The amounts of gases produced by steam gasification of carbon deposition were fairly constant (in the range 0.08 - 


\section{WILEY-VCH}

$0.22 \mathrm{mmol} / \mathrm{g}_{\mathrm{CeO}_{2}}$ for $\mathrm{H}_{2}\left(\mathrm{C}+\mathrm{H}_{2} \mathrm{O}\right), 0.11-0.22 \mathrm{mmol} / \mathrm{g}_{\mathrm{CeO} 2}$ for $\mathrm{H}_{2}\left(\mathrm{C}+2 \mathrm{H}_{2} \mathrm{O}\right), 0.08-0.22$

$\mathrm{mmol} / \mathrm{g}_{\mathrm{CeO}_{2}}$ for $\mathrm{CO}\left(\mathrm{C}+\mathrm{H}_{2} \mathrm{O}\right)$, and $0.06-0.11 \mathrm{mmol} / \mathrm{g}_{\mathrm{CeO}_{2}}$ for $\left.\mathrm{CO}_{2}\left(\mathrm{C}+2 \mathrm{H}_{2} \mathrm{O}\right)\right)$. Moreover, the $\delta_{\text {ox }}$ values were in the range $0.33-0.35$, thus matching well the $\delta_{\text {red }}$ values (Figure 12) and demonstrating complete reduced ceria re-oxidation during cycling. These results thus confirmed the performance stability of ceria for solar CLRM.

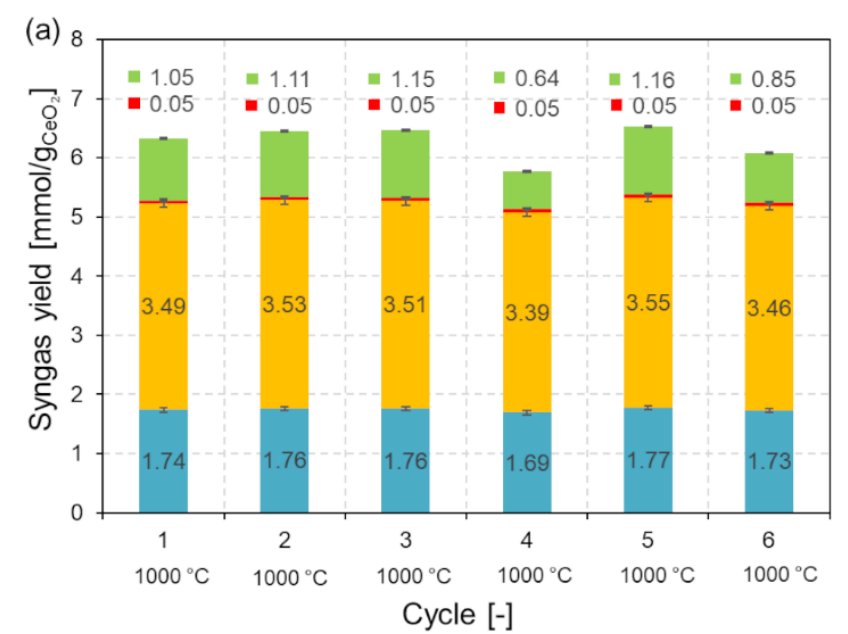

(b) $\equiv \mathrm{CO}\left(\mathrm{CeO}_{2}+\mathrm{CH}_{4}\right)=\mathrm{H}_{2}\left(\mathrm{CeO}_{2}+\mathrm{CH}_{4}\right)=\mathrm{CO}_{2}\left(\mathrm{CeO}_{2}+\mathrm{CH}_{4}\right)=\mathrm{H}_{2}\left(\mathrm{CH}_{4}\right.$ Cracking)

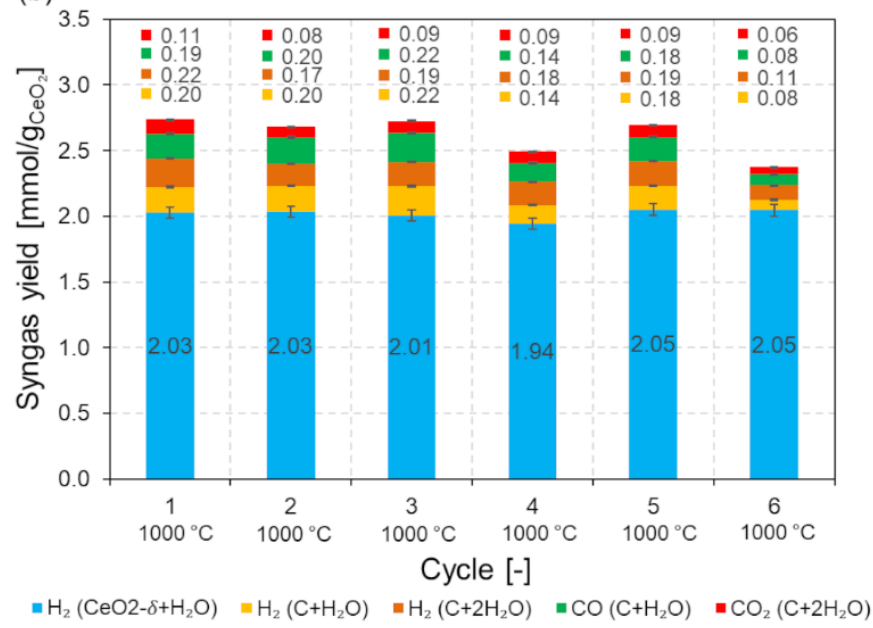

Figure 11. Syngas yields for both reduction and re-oxidation of ceria powder during 6 consecutive redox cycles at $1000{ }^{\circ} \mathrm{C}$. 


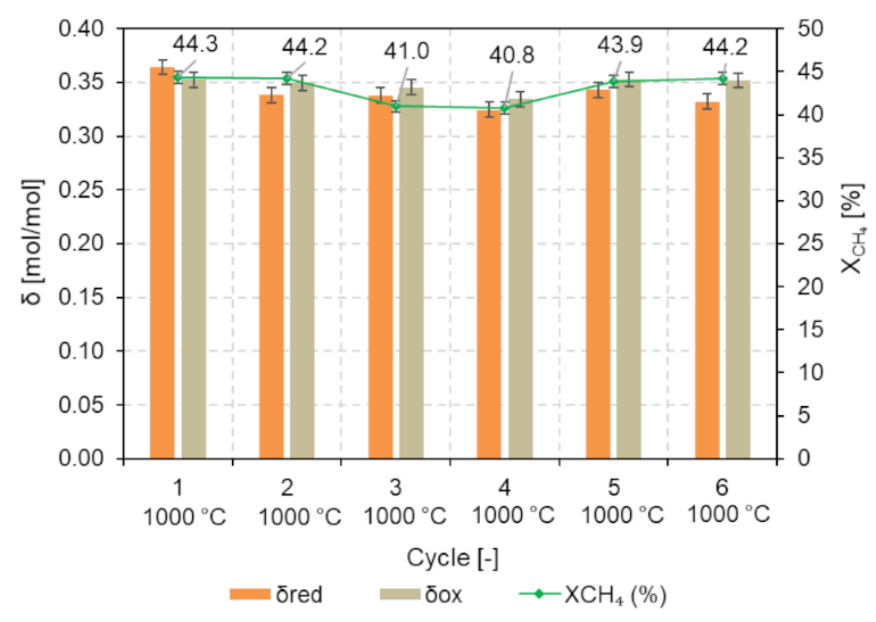

Figure 12. Comparison of $\delta_{\text {red }}$ and $\delta_{\text {ox }}$ in ceria powder along with $\mathrm{CH}_{4}$ conversion during 6 consecutive redox cycles performed at $1000{ }^{\circ} \mathrm{C}$.

In order to confirm the experimental repeatability and assess the effect of material shaping, a ceria reticulated porous foam (total mass: $18.37 \mathrm{~g}$, Figure S3d) was prepared and then employed for solar CLRM. Experiments were carried out with 12 successive cycles at $950{ }^{\circ} \mathrm{C}$ ( 1 cycle $), 1000{ }^{\circ} \mathrm{C}(10$ cycles $)$ and $1050{ }^{\circ} \mathrm{C}(1$ cycle $)$. The reacting and carrier gas flow rates were unchanged $\left(0.2 \mathrm{Nl} / \mathrm{min}\right.$ for $\mathrm{CH}_{4}, 200 \mathrm{mg} / \mathrm{min}$ for $\mathrm{H}_{2} \mathrm{O}$, and $0.2 \mathrm{Nl} / \mathrm{min}$ for $\mathrm{Ar}$ ). As expected, stable patterns in the $\mathrm{H}_{2}\left(\mathrm{CeO}_{2}+\mathrm{CH}_{4}\right), \mathrm{CO}$, and $\mathrm{CO}_{2}$ yields over 10 cycles at $1000{ }^{\circ} \mathrm{C}$ were evidenced, in the ranges $3.48-3.64 \mathrm{mmol} / \mathrm{g}_{\mathrm{CeO}_{2}}$ for $\mathrm{H}_{2}\left(\mathrm{CeO}_{2}+\mathrm{CH}_{4}\right), 1.74-1.82$ $\mathrm{mmol} / \mathrm{g}_{\mathrm{CeO}_{2}}$ for $\mathrm{CO}$, and $0.07-0.10 \mathrm{mmol} / \mathrm{g}_{\mathrm{CeO}_{2}}$ for $\mathrm{CO}_{2}$ (Figure 13a), thereby resulting in stable total syngas yield $\left(5.67-6.80 \mathrm{mmol} / \mathrm{g}_{\mathrm{CeO}_{2}}\right), \delta_{\text {red }}(0.35-0.38)$ and $\mathrm{X}_{\mathrm{CH}_{4}}$ evolution profile (46.9-60.9\%, Figure 14) as well as constant selectivity (96.5-98.2\% for $\mathrm{H}_{2}$ and $95.1-98.1 \%$ for $\mathrm{CO}$, Table $\mathrm{S} 1)$. The $\mathrm{H}_{2}\left(\mathrm{CH}_{4}\right.$ cracking) yield at $1000^{\circ} \mathrm{C}$ fluctuated slightly (in the range 0.35-1.27 mmol $/ \mathrm{g}_{\mathrm{CeO}_{2}}$ ) because of a small difference in the $\mathrm{CH}_{4}$ injection duration, as mentioned before. When either increasing or decreasing the temperature $\left(1050{ }^{\circ} \mathrm{C}\right.$ at cycle \#5 or $950{ }^{\circ} \mathrm{C}$ at cycle \#6), the total syngas yield varied significantly because of a change in the reaction kinetics. The maximum total syngas yield $\left(7.48 \mathrm{mmol} / \mathrm{g}_{\mathrm{CeO}_{2}}\right)$ was consequently found at the maximum temperature $\left(1050{ }^{\circ} \mathrm{C}\right)$, demonstrating kinetic rate improvement (Figure 15). 


\section{WILEY-VCH}

Moreover, the $\mathrm{H}_{2}\left(\mathrm{CH}_{4}\right.$ cracking $)$ yield was negligible at $900{ }^{\circ} \mathrm{C}$, in agreement with the lowest $\mathrm{X}_{\mathrm{CH} 4}(20 \%)$; in contrast, it was maximal $\left(2.0 \mathrm{mmol} / \mathrm{g}_{\mathrm{CeO}_{2}}\right)$ at the highest temperature $\left(1050{ }^{\circ} \mathrm{C}\right)$ in agreement with the highest $\mathrm{X}_{\mathrm{CH}_{4}}(65.9 \%)$, thereby indicating that the extent of $\mathrm{CH}_{4}$ cracking reaction is strongly dependent on the temperature. ${ }^{[9]}$ For these reasons, a temperature trade-off at $1000{ }^{\circ} \mathrm{C}$ is advocated to hasten the kinetic rate of ceria reduction while alleviating the side reaction associated with $\mathrm{CH}_{4}$ cracking. In order to examine the reaction kinetics for ceria during methane-induced reduction, the Arrhenius expression was applied to evaluate the effect of temperature on ceria reduction rates.

$k=A \cdot \exp \left(-E_{a} / R T\right)$

Where $k$ is the reaction rate constant, $A$ is the pre-exponential factor, $E_{a}$ is the activation energy, $R$ is the gas constant and $T$ is absolute temperature.

The reaction rate constants $(\mathrm{k})$ were quantified from the peak production rates of $\mathrm{H}_{2}$ and $\mathrm{CO}$ at $950{ }^{\circ} \mathrm{C}$ (cycle \#6), $1000{ }^{\circ} \mathrm{C}$ (cycle \#4), and $1050{ }^{\circ} \mathrm{C}$ (cycle \#5). The logarithm evolution of the reaction rates versus inverse temperature (Equation 22) was subsequently plotted (Figure 15) to determine the activation energy $\left(E_{a}\right)$ of the ceria reduction process. As a result, the slope of $\ln \mathrm{k}$ for both $\mathrm{H}_{2}$ and $\mathrm{CO}$ production rates increased linearly with the inverse temperature. The $\mathrm{E}_{\mathrm{a}}$ values were $114.2 \mathrm{~kJ} / \mathrm{mol}$ for $\mathrm{H}_{2}$ and $93.4 \mathrm{~kJ} / \mathrm{mol}$ for $\mathrm{CO}$. The $\mathrm{E}_{\mathrm{a}}$ value related to $\mathrm{H}_{2}$ production rates was slightly higher compared to that of $\mathrm{CO}$ as a result of the side reaction effect attributed to $\mathrm{CH}_{4}$ cracking. This side reaction produces additional $\mathrm{H}_{2}$ and thus modifies the global $\mathrm{H}_{2}$ production rate arising only from the reaction with ceria. In contrast, $\mathrm{CO}$ is only produced from methane reforming (Equation 12) and better represents the kinetics of ceria reduction reaction. In addition, the $\mathrm{E}_{\mathrm{a}}$ for reduction was consistent with previous study [30]. 


\section{WILEY-VCH}

Regarding oxidation (Figure 13b), the $\mathrm{H}_{2}\left(\mathrm{CeO}_{2-\delta}+\mathrm{H}_{2} \mathrm{O}\right)$ yield was stable at $1000{ }^{\circ} \mathrm{C}$ (in the range 2.04-2.17 mmol/g $\mathrm{g}_{\mathrm{CeO}_{2}}$ ), except for cycles \#5 and \#6 caused by the temperature impact during the reduction step. Likewise, the $\mathrm{H}_{2}\left(\mathrm{C}+\mathrm{H}_{2} \mathrm{O}\right), \mathrm{H}_{2}\left(\mathrm{C}+2 \mathrm{H}_{2} \mathrm{O}\right), \mathrm{CO}\left(\mathrm{C}+\mathrm{H}_{2} \mathrm{O}\right)$, and $\mathrm{CO}_{2}\left(\mathrm{C}+\mathrm{H}_{2} \mathrm{O}\right)$ yields at $1000{ }^{\circ} \mathrm{C}$ were fairly constant in negligible amounts $(0.11-0.18,0.04-$ $0.10,0.11-0.18$, and $0.02-0.05 \mathrm{mmol} / \mathrm{g}_{\mathrm{CeO}_{2}}$, respectively). The total syngas yield was in the range $2.38-2.57 \mathrm{mmol} / \mathrm{g}_{\mathrm{CeO}_{2}}$, and $\delta_{\mathrm{ox}}$ was in the range $0.35-0.37$ (consistent with $\delta_{\text {red }}$ ) (Figure 14). Thus, the cycling stability of ceria was validated with respect to stable patterns in produced syngas, $\delta$, and $\mathrm{X}_{\mathrm{CH}_{4}}$, thereby outperforming iron oxide (whether in the form of powder or foam structures) and exhibiting superior thermochemical stability over cycles.

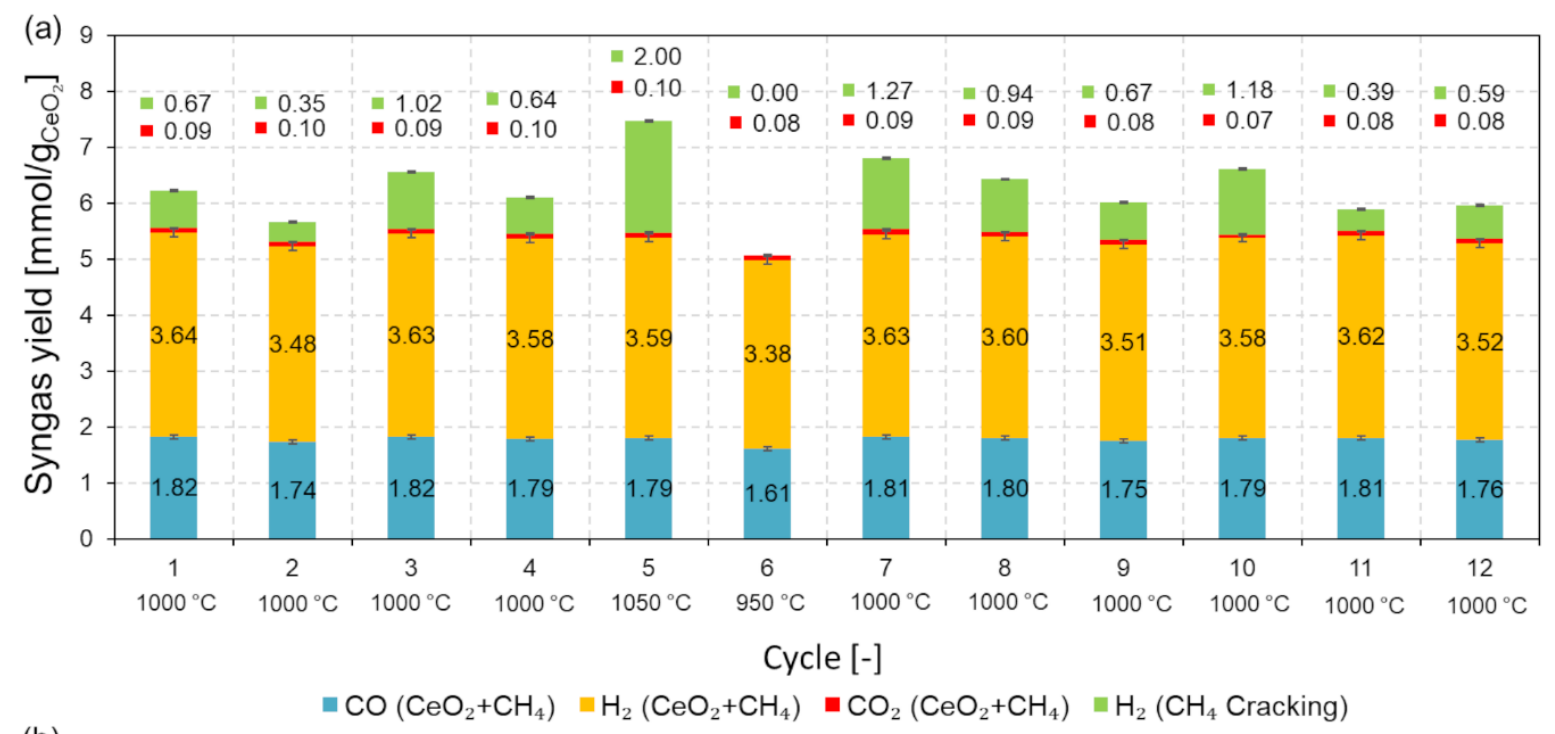

(b)

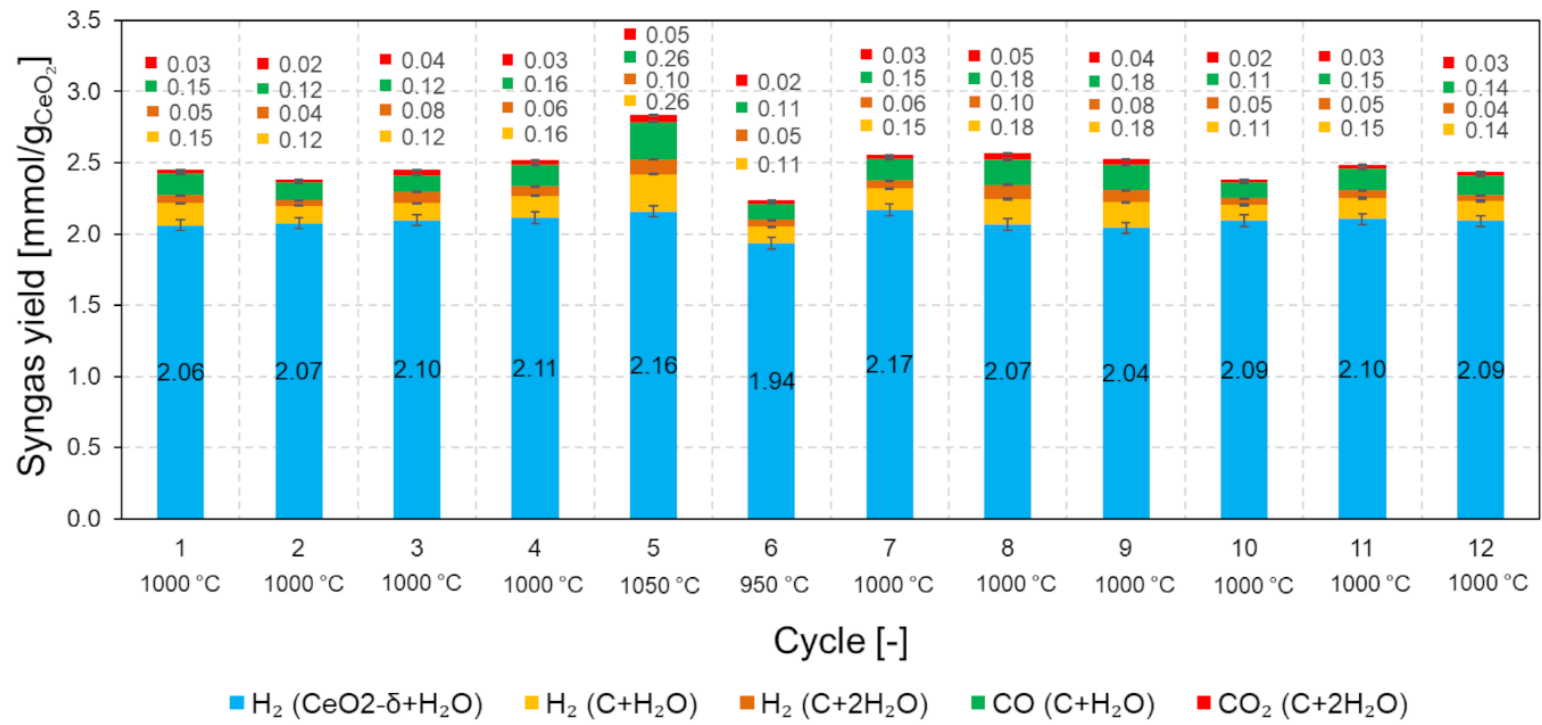




\section{WILEY-VCH}

Figure 13. Syngas yields for both reduction and re-oxidation of ceria porous foam during 12 consecutive redox cycles performed isothermally.

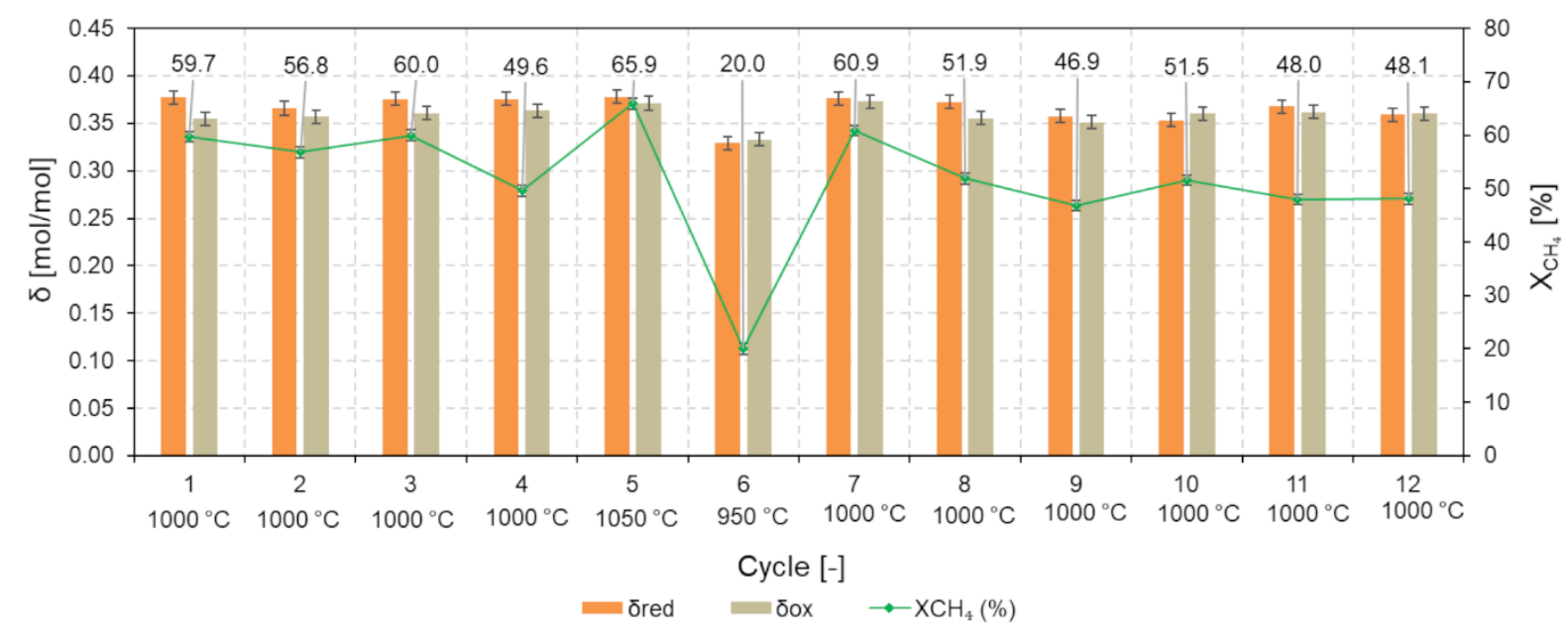

Figure 14. Comparison of $\delta_{\text {red }}$ and $\delta_{\text {ox }}$ in ceria foam along with $\mathrm{CH}_{4}$ conversion during 12 consecutive redox cycles performed isothermally.

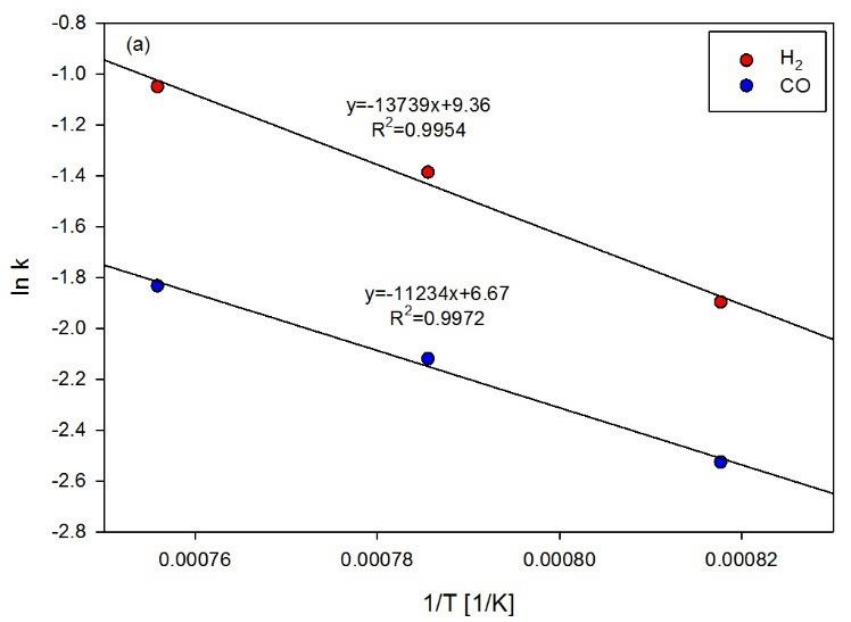

Figure 15. Arrhenius plot for $\mathrm{H}_{2}$ and $\mathrm{CO}$ production rates in the range $950-1050{ }^{\circ} \mathrm{C}$ during ceria foam reduction.

The main advantages of $\mathrm{CeO}_{2}$ when compared with iron oxide have thus been highlighted, including faster reaction rates, reversibility and cycling stability. Besides, combining both 


\section{WILEY-VCH}

cerium and iron oxides may promote the oxygen carrier performance by taking advantage of their mutual benefits, while alleviating the drawbacks of both iron oxide (sintering and poor reaction reversibility) and cerium oxide (higher cost and moderate oxygen exchange capacity).

\section{Conclusion}

Solar chemical looping reforming of methane (CLRM) combined with isothermal $\mathrm{H}_{2} \mathrm{O}$ splitting over iron and cerium oxides was thermodynamically and experimentally investigated in a directly-irradiated lab-scale solar reactor using concentrated solar heat for supplying process energy. The thermodynamic analysis provided insights into the theoretically possible chemical reactions and equilibrium species distribution for comparison with experimental results.

Iron oxide $\left(\mathrm{Fe}_{2} \mathrm{O}_{3}\right)$ in the form of powder or porous foam showed relatively low reaction rate when reacting with methane at $1000{ }^{\circ} \mathrm{C}$, and the reduction extent strongly depended on temperature. However, increasing the temperature $\left(\geq 1100^{\circ} \mathrm{C}\right)$ resulted in strong sintering (dense structure), lowered syngas yield, and material deactivation. In contrast, cerium oxide $\left(\mathrm{CeO}_{2}\right)$ showed faster reaction rates than iron oxide when reacting with methane at $1000{ }^{\circ} \mathrm{C}$, and increasing the temperature between $900-1050{ }^{\circ} \mathrm{C}$ promoted syngas yield and ceria reduction kinetics (with activation energy for ceria foam reduction in the range 93.4-114.2 $\mathrm{kJ} / \mathrm{mol}$ ). Stable patterns in the ceria reduction and oxidation extents, $\mathrm{CH}_{4}$ conversion, and syngas yields during successive cycles for both powder and reticulated porous foam demonstrated remarkable thermochemical cycling stability.

Thus, utilizing iron oxide $\left(\mathrm{Fe}_{2} \mathrm{O}_{3}\right)$ as oxygen carrier is not suitable for solar CLRM with respect to poor material re-oxidation capability; instead, iron oxide reduction with $\mathrm{CH}_{4}$ could be an attractive route for producing both metallic iron and syngas via $\mathrm{CO}_{2}$-free solar metallurgical process. For these reasons, the use of cerium oxide as oxygen carrier for solar CLRM is more appropriate than iron oxide. The advantages of using ceria as oxygen carrier 


\section{WILEY-VCH}

have thus been demonstrated, such as faster reaction rates and superior thermochemical cycling stability (oxygen can be released and recovered reversibly in the oxide crystal lattice), which are key assets for the two-step solar chemical-looping process. Combining concentrated solar energy and CLRM was shown to be a promising and sustainable pathway toward clean solar fuels. Further work should be focused on taking the benefits of both iron and cerium oxides by considering their mixed oxides to promote the oxygen carrier performance.

\section{Supporting Information}

Supporting Information is available from the Wiley Online Library or from the author.

\section{Acknowledgements}

The King Mongkut's Institute of Technology Ladkrabang (KMITL), Thailand and the FrancoThai scholarship program are gratefully acknowledged for fellowship granting.

Received: ((will be filled in by the editorial staff))

Revised: ((will be filled in by the editorial staff)) Published online: ((will be filled in by the editorial staff))

\section{References}

[1] Q. Zheng, C. Janke, R. Farrauto, Appl. Catal. B Environ. 2014, 160-161, 525-533.

[2] Q. Song, R. Xiao, Y. Li, L. Shen, Ind. Eng. Chem. Res. 2008, 47, 4349-4357.

[3] G. Zhang, Y. Dong, M. Feng, Y. Zhang, W. Zhao, H. Cao, Chem. Eng. J. 2010, 156, 519-523.

[4] G. Zhang, A. Su, Y. Du, J. Qu, Y. Xu, J. Colloid Interface Sci. 2014, 433, 149-155.

[5] G. Zhang, Y. Du, Y. Xu, Y. Zhang, J. Ind. Eng. Chem. 2014, 20, 1677-1683.

[6] K. J. Warren, J. Reim, K. Randhir, B. Greek, R. Carrillo, D. W. Hahn, J. R. Scheffe, Energy Technol. 2017, 5, 2138-2149.

[7] S. Chuayboon, S. Abanades, S. Rodat, Chem. Eng. J. 2019, 356, 756-770. 


\section{WILEY-VCH}

[8] P.T. Krenzke, J.R. Fosheim, J. Zheng, J.H. Davidson, Int. J. Hydrogen Energy 2016, $41,12799-12811$.

[9] J. R. Fosheim, B. J. Hathaway, J. H. Davidson, Energy 2019, 169, 597-612.

[10] C. Wieckert, A. Steinfeld, J. Sol. Energy Eng. 2001, 124, 55-62.

[11] T. Kodama, T. Shimizu, A. Aoki, Y. Kitayama, Energy \& Fuels 1997, 11, 1257-1263.

[12] H. I. Villafan-Vidales, S. Abanades, M. Montiel-Gonzalez, H. Romero, Energy Technol 2016, 5, 692-702.

[13] M. Welte, K. Warren, J. R. Scheffe, A. Steinfeld, Ind. Eng. Chem. Res. 2017, 56, 10300-10308.

[14] S. Abanades, P. Charvin, G. Flamant, P. Neveu, Energy 2006, 31, 2805-22.

[15] A. Steinfeld, A. Frei, P. Kuhn, D. Wuillemin, Int. J. Hydrogen Energy 1995, 20, 793804.

[16] M. E. Gálvez, A. Frei, G. Albisetti, G. Lunardi, A. Steinfeld, Int. J. Hydrogen Energy 2008, 33, 2880-2890.

[17] K. Otsuka, M. Hatano, A. Morikawa, J. Catal. 1983, 79, 493-496.

[18] K. Otsuka, T. Ushiyama, I. Yamanaka, Chem. Lett. 1993, 22, 1517-1520.

[19] K. Li, H. Wang, Y. Wei, D. Yan, Appl. Catal. B Environ. 2010, 97, 361-372.

[20] K. Li, H. Wang, Y. Wei, D. Yan, Chem. Eng. J. 2010, 156, 512-518.

[21] K. Otsuka, Y. Wang, M. Nakamura, Appl. Catal. A Gen. 1999, 183, 317-324.

[22] C. L. Muhich, S. Blaser, M. C. Hoes, A. Steinfeld, Int. J. Hydrogen Energy 2018, 43, 18814-18831.

[23] J. T. Jang, K. J. Yoon, G. Y. Han, Sol. Energy 2014, 101, 29-39.

[24] H. H. Jeong, J. H. Kwak, G. Y. Han, K. J. Yoon, Int. J. Hydrogen Energy 2011, 36, $15221-15230$.

[25] T, Shimizu, Y, Kitayama, T, Kodama, Energy \& Fuels 2001, 15, 463-469.

[26] L. Wang, T. Ma, Z. Chang, H. Li, M. Fu, X. Li, Sol. Energy 2019, 177, 772-781. 


\section{WILEY-VCH}

[27] A. Steinfeld, P. Kuhn, J. Karni, Energy 1993, 18, 239-249.

[28] K. S. Kang, C. H. Kim, K. K. Bae, W. C. Cho, S. H. Kim, C. S. Park, Int. J. Hydrogen Energy 2010, 35, 12246-12254.

[29] P. Furler, J. Scheffe, D. Marxer, M. Gorbar, A. Bonk, U. Vogt, Phys. Chem. Chem. Phys. 2014, 16, 10503-10511.

[30] M. M. Nair, S. Abanades, Energy \& Fuels 2016, 30, 6050-6058.

[31] O. T. Sørensen, J. Solid State Chem. 1976, 18, 217-233.

[32] A. C. Gladen, J. H. Davidson, Sol. Energy 2016, 139, 524-532.

[33] C. Lu, K. Li, H. Wang, X. Zhu, Y. Wei, M. Zheng, Appl. Energy 2018, 211, 1-14.

[34] M. F. Bleeker, H. J. Veringa, S. R. A. Kersten, Appl. Catal. A Gen. 2009, 357, 5-17.

[35] S. Abanades, G. Flamant, Sol. Energy 2006, 80, 1611-1623.

[36] X. Zhu, H. Wang, Y. Wei, K. Li, X. Cheng, J. Nat. Gas Chem. 2011, 20, 281-286.

[37] P. T. Krenzke, J. H. Davidson, Energy \& Fuels 2014, 28, 4088-4095.

[38] X. Zhu, K. Li, Y. Wei, Energy \& Fuels 2014, 28, 754-760. 


\section{WILEY-VCH}

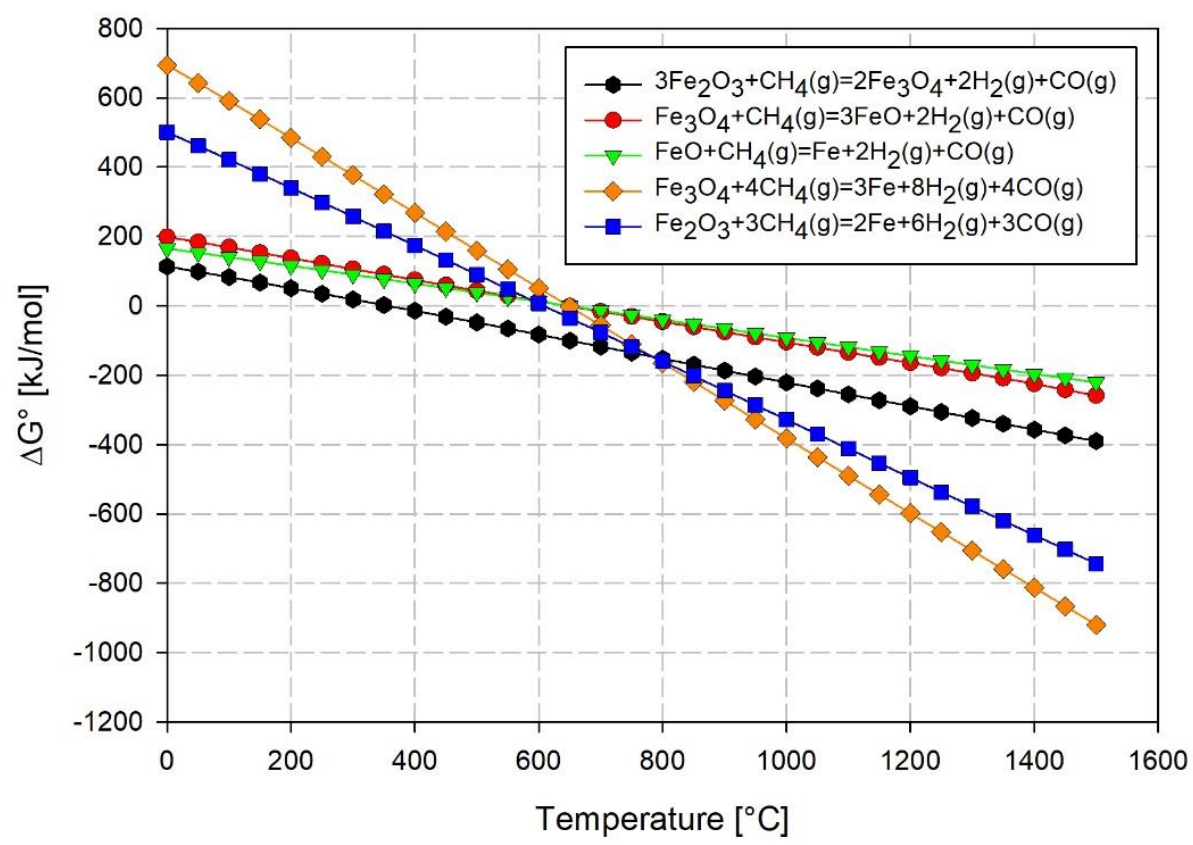

Figure 1. $\Delta \mathrm{G}^{\circ}$ variations for iron oxides reduction with methane as a function of temperature.

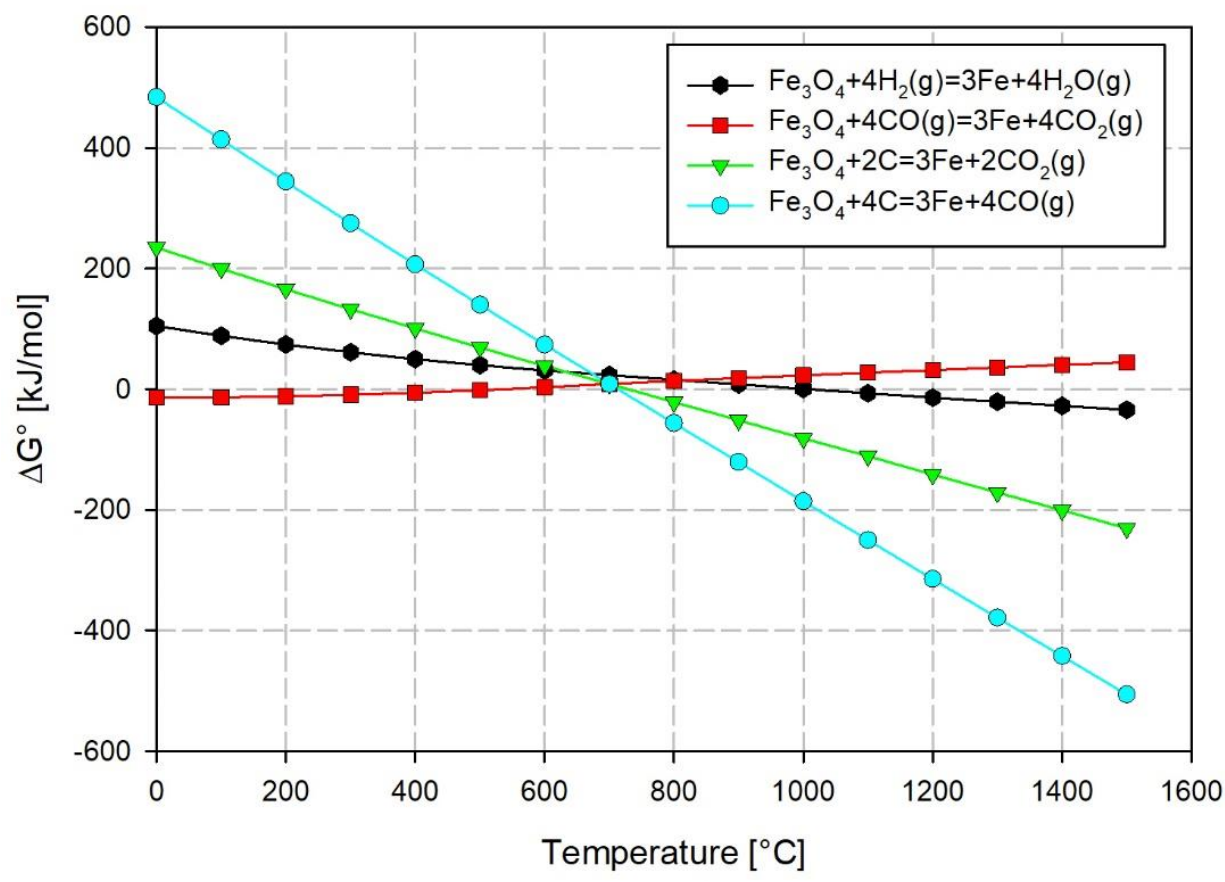

Figure 2. $\Delta \mathrm{G}^{\circ}$ variations for the reactions of $\mathrm{Fe}_{3} \mathrm{O}_{4}$ with $\mathrm{H}_{2}, \mathrm{CO}$, and $\mathrm{C}$ as a function of temperature. 


\section{WILEY-VCH}

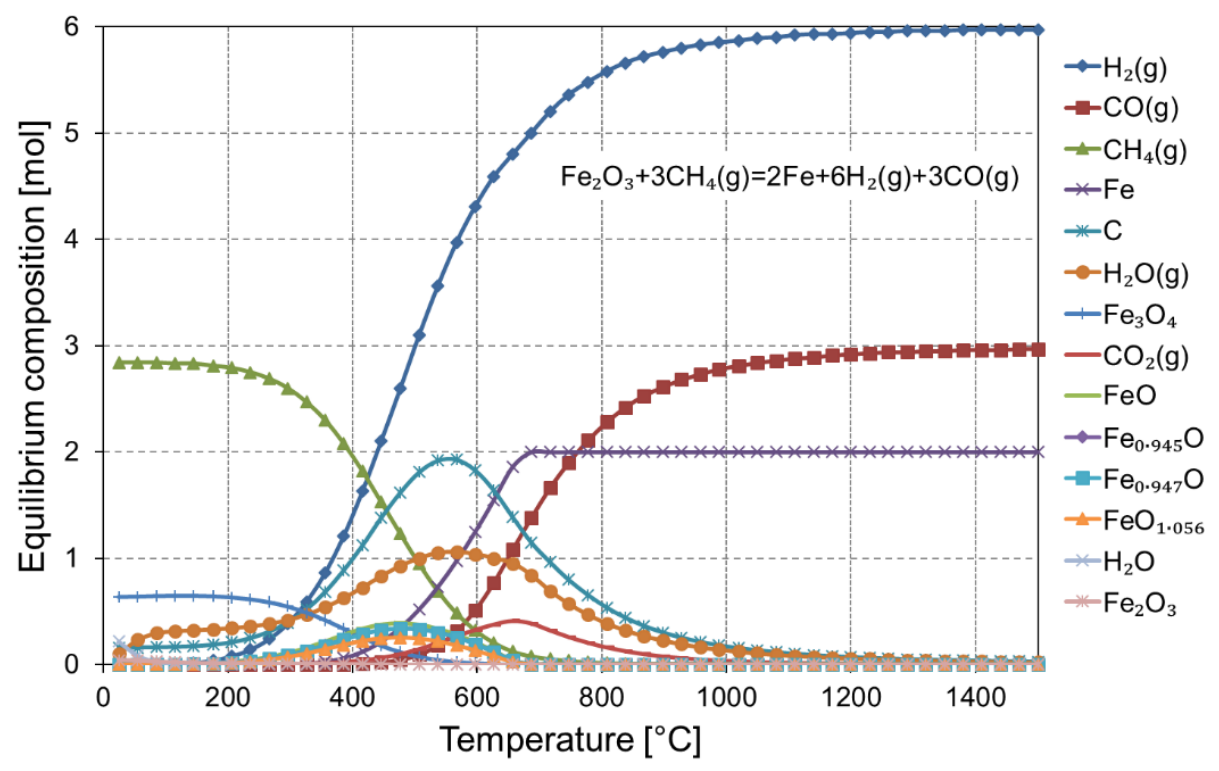

Figure 3. Thermodynamic equilibrium composition of methane reforming over $\mathrm{Fe}_{2} \mathrm{O}_{3}$ as a function of temperature at 1 bar.

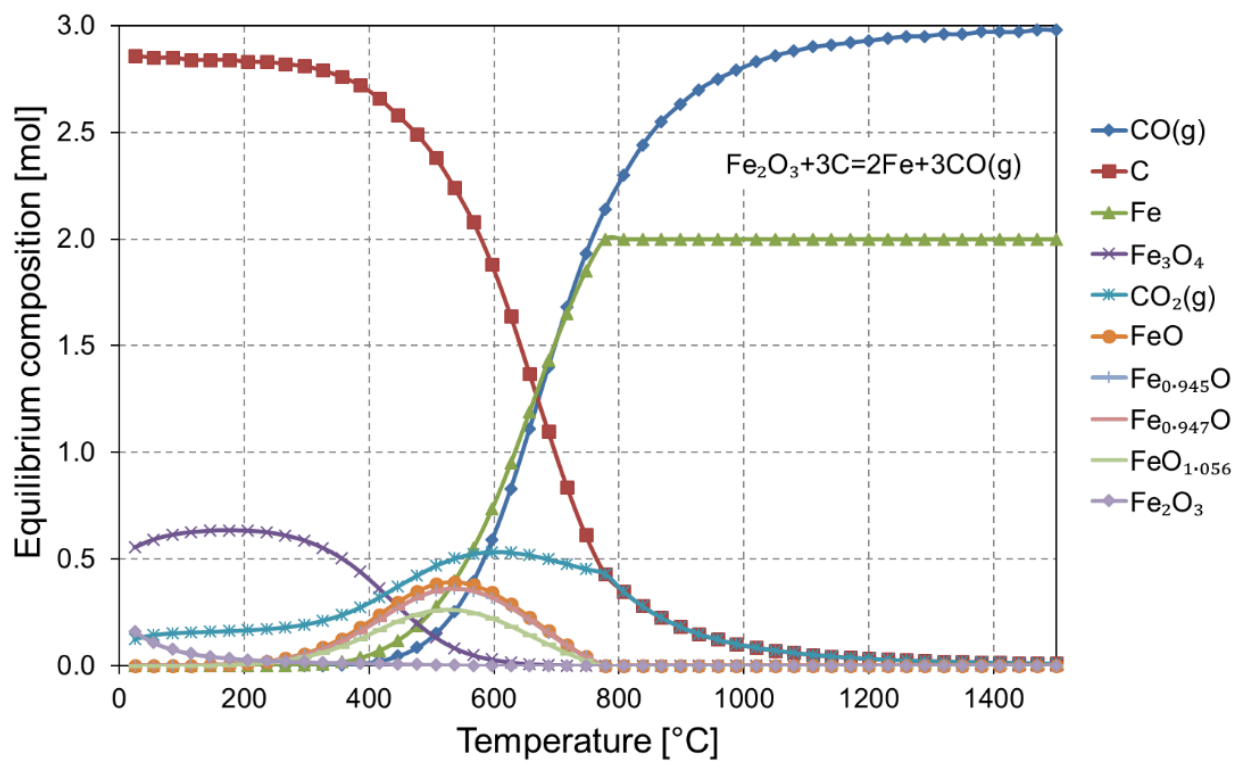

Figure 4. Thermodynamic equilibrium composition of $\mathrm{Fe}_{2} \mathrm{O}_{3}$ carbothermal reduction as a function of temperature at 1 bar. 


\section{WILEY-VCH}

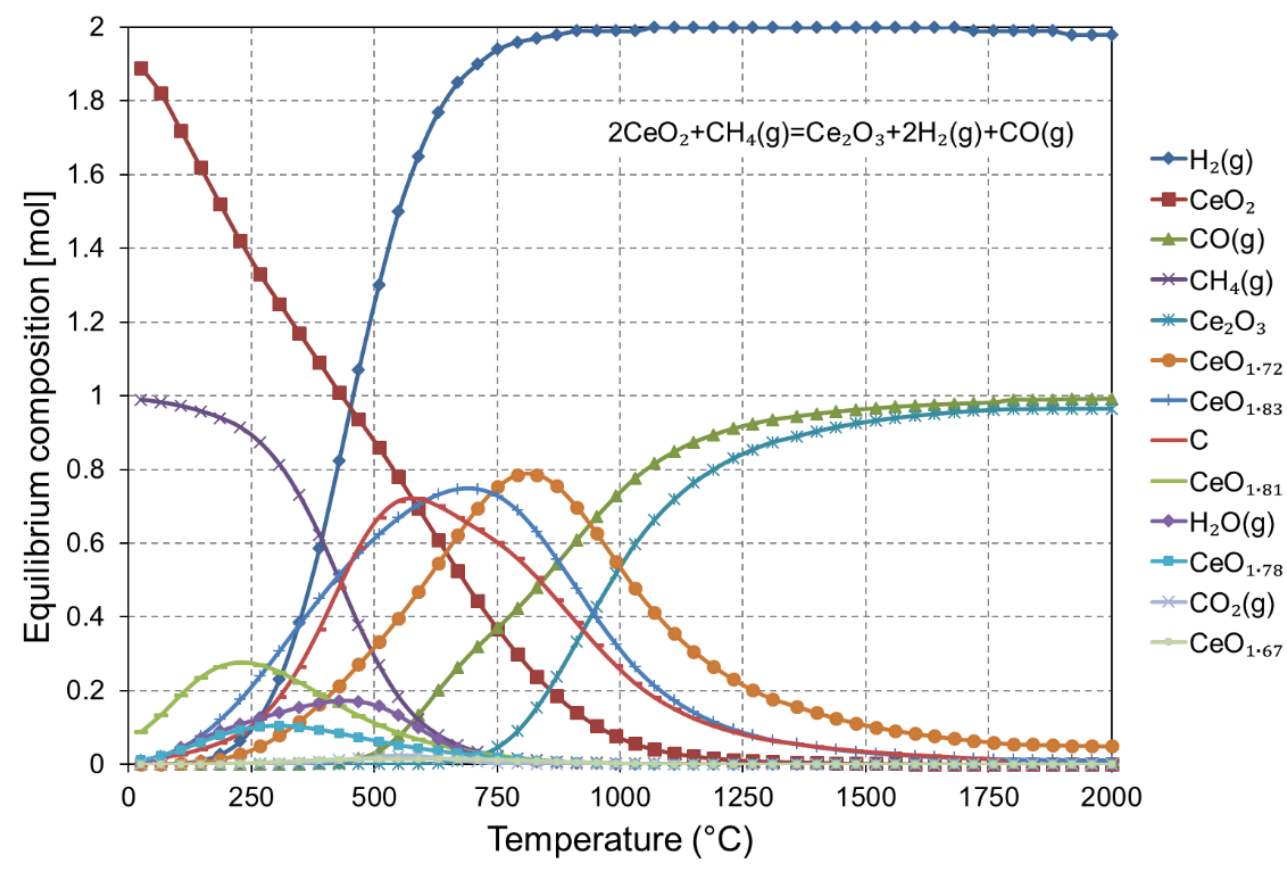

Figure 5. Thermodynamic equilibrium composition of methane reforming over ceria as a function of temperature at 1 bar.
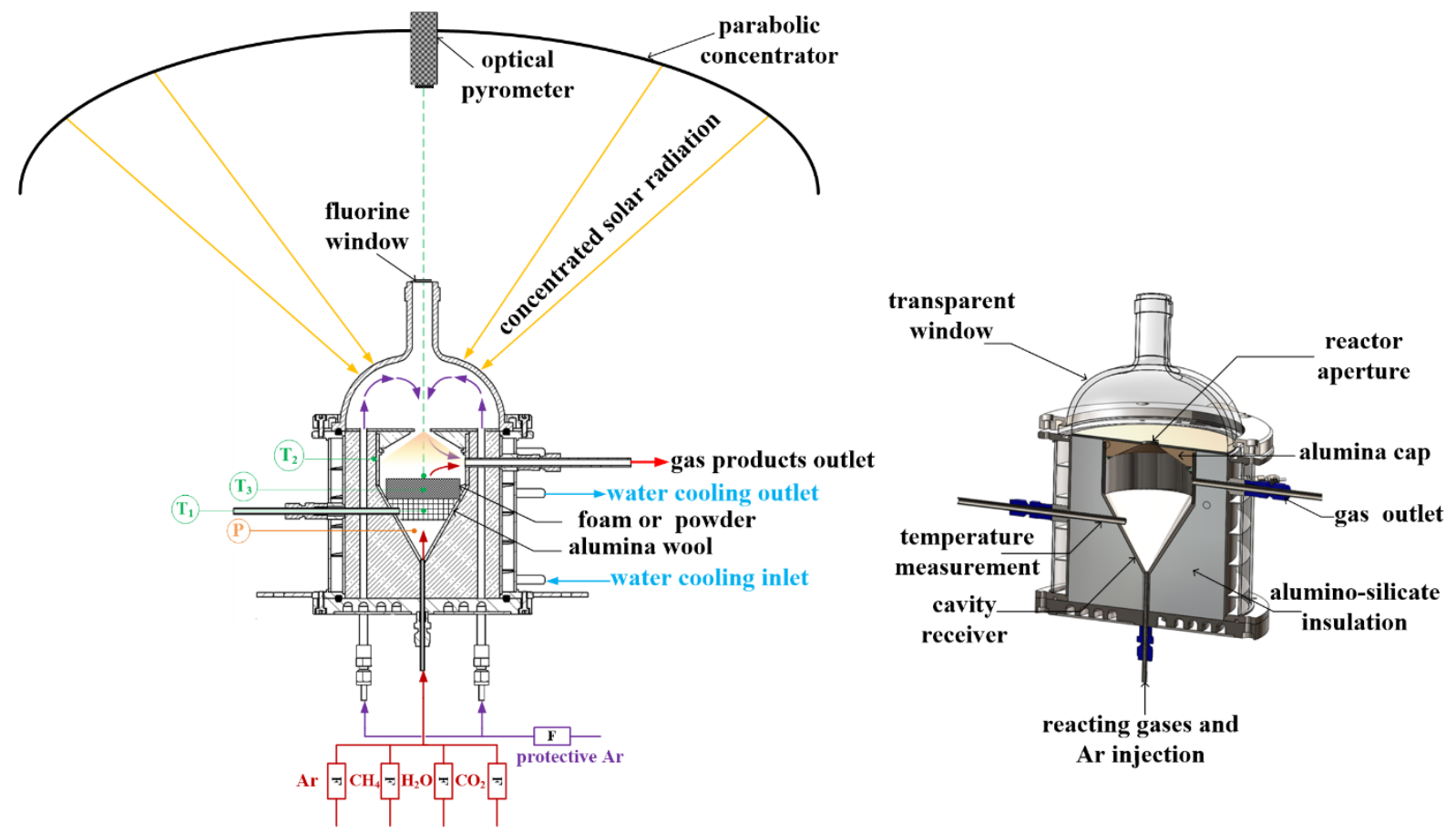


\section{WILEY-VCH}

Figure 6. Schematic of the $1.5 \mathrm{~kW}_{\text {th }}$ directly-irradiated solar reactor and external components (left) and 3D cross section of the solar reactor (right).

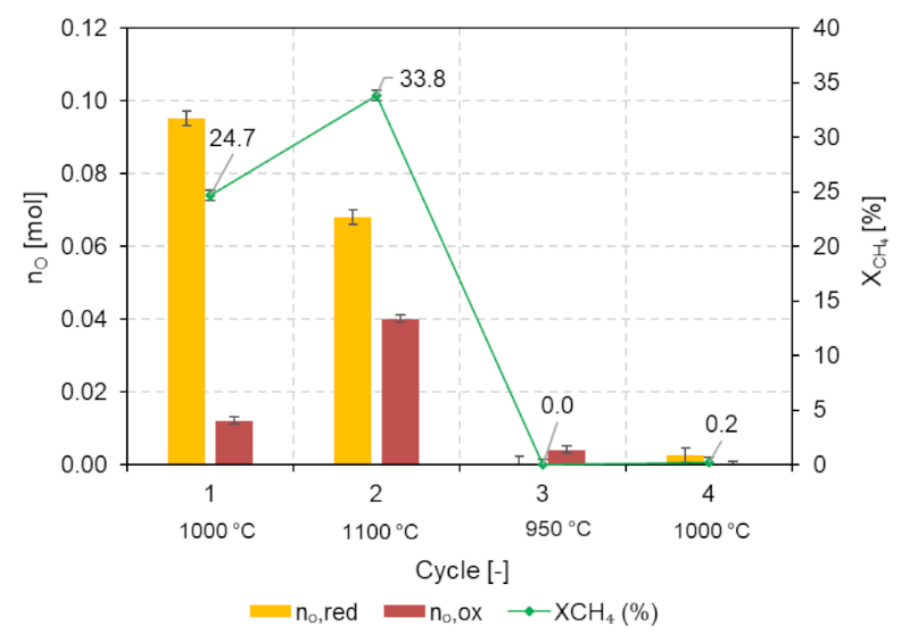

Figure 7. Comparison of $\mathrm{n}_{\mathrm{O}, \text { red }}$ and $\mathrm{n}_{\mathrm{O}, \mathrm{ox}}$ along with $\mathrm{CH}_{4}$ conversion during four consecutive redox cycles with iron oxide powder performed at $950-1100{ }^{\circ} \mathrm{C}$. 
WILEY-VCH
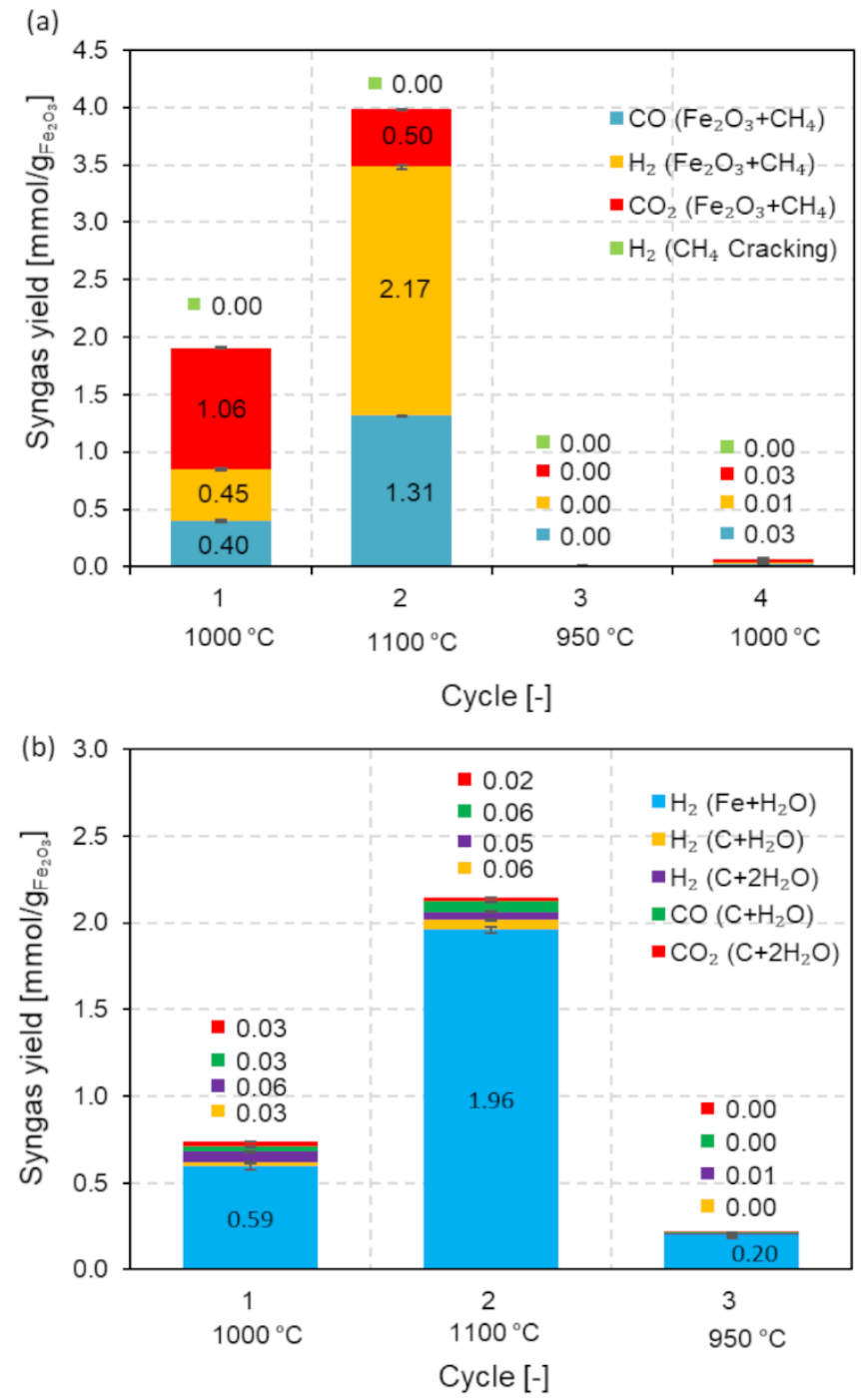

Figure 8. Syngas yields for (a) iron oxide powder reduction with $\mathrm{CH}_{4}$ and (b) oxidation with $\mathrm{H}_{2} \mathrm{O}$ during isothermal cycles at temperatures in the range $950-1100{ }^{\circ} \mathrm{C}$. 


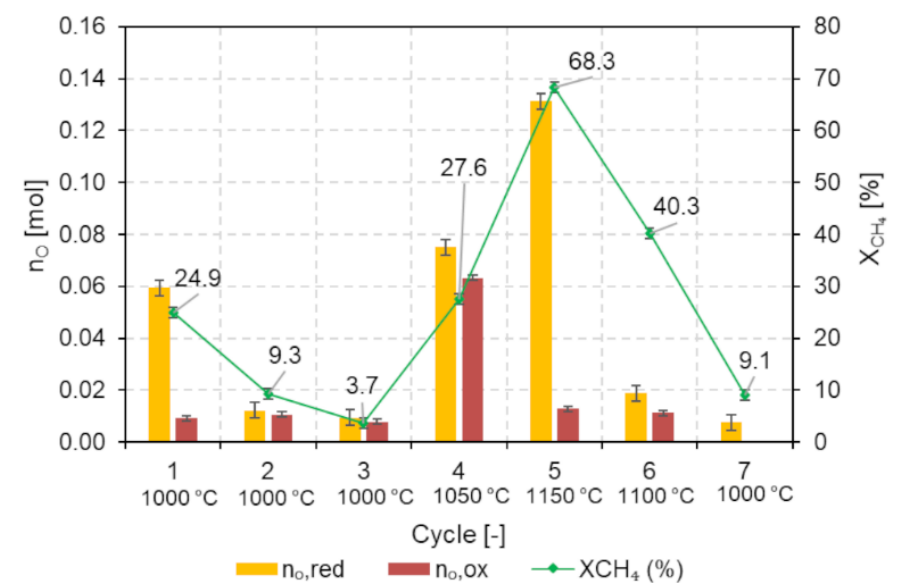

Figure 9. Comparison of $\mathrm{n}_{\mathrm{O} \text {,red }}$ and $\mathrm{n}_{\mathrm{O}, \mathrm{ox}}$ along with $\mathrm{CH}_{4}$ conversion during seven consecutive redox cycles with iron oxide foam performed at $1000-1150{ }^{\circ} \mathrm{C}$.
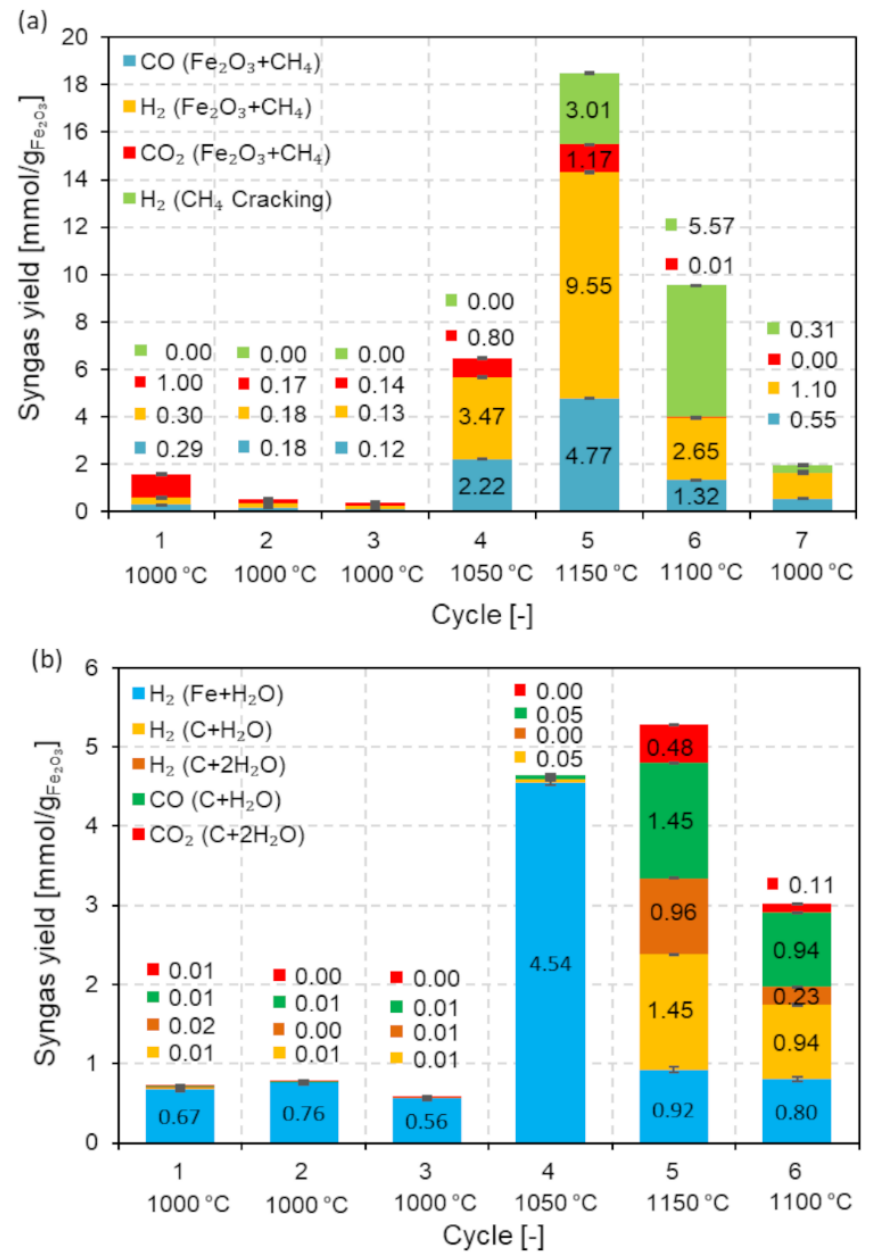

Figure 10. Syngas yields for (a) iron oxide reticulated porous foam reduction with $\mathrm{CH}_{4}$ and (b) oxidation with $\mathrm{H}_{2} \mathrm{O}$ cycled isothermally at temperatures in the range $1000-1150{ }^{\circ} \mathrm{C}$. 

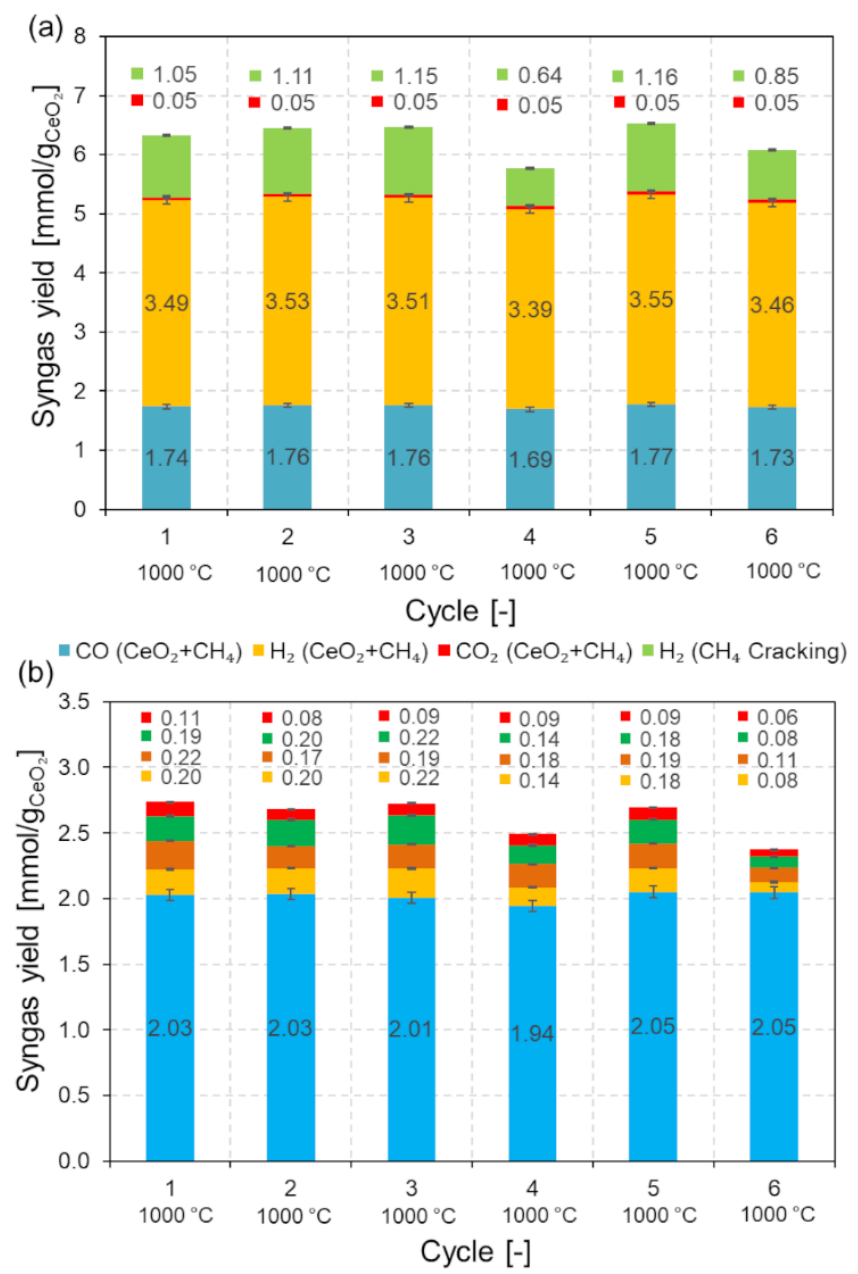

$=\mathrm{H}_{2}\left(\mathrm{CeO} 2-\delta+\mathrm{H}_{2} \mathrm{O}\right)=\mathrm{H}_{2}\left(\mathrm{C}+\mathrm{H}_{2} \mathrm{O}\right)=\mathrm{H}_{2}\left(\mathrm{C}+2 \mathrm{H}_{2} \mathrm{O}\right)=\mathrm{CO}\left(\mathrm{C}+\mathrm{H}_{2} \mathrm{O}\right)=\mathrm{CO}_{2}\left(\mathrm{C}+2 \mathrm{H}_{2} \mathrm{O}\right)$

Figure 11. Syngas yields for both reduction and re-oxidation of ceria powder during 6 consecutive redox cycles at $1000{ }^{\circ} \mathrm{C}$.

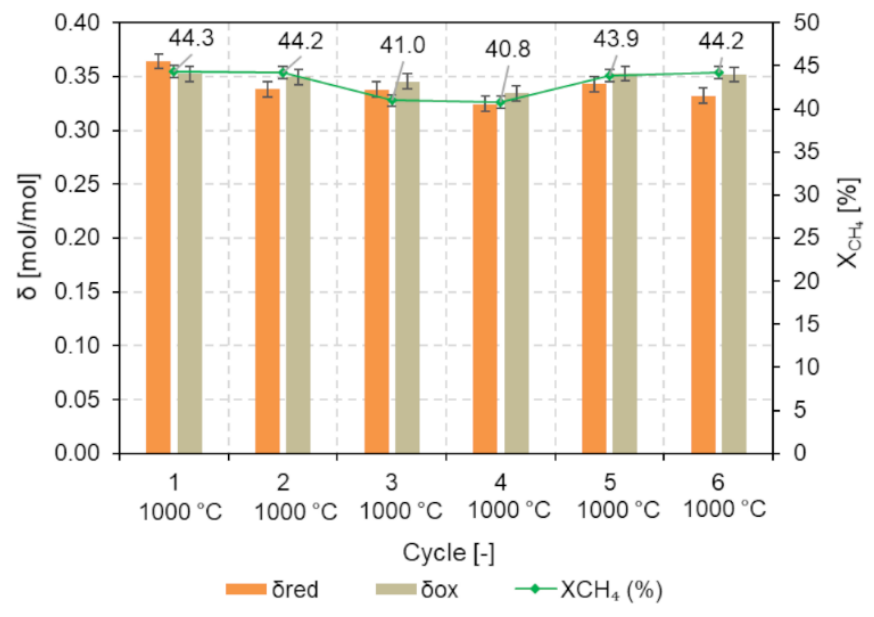

Figure 12. Comparison of $\delta_{\text {red }}$ and $\delta_{\text {ox }}$ in ceria powder along with $\mathrm{CH}_{4}$ conversion during 6 consecutive redox cycles performed at $1000{ }^{\circ} \mathrm{C}$. 


\section{WILEY-VCH}

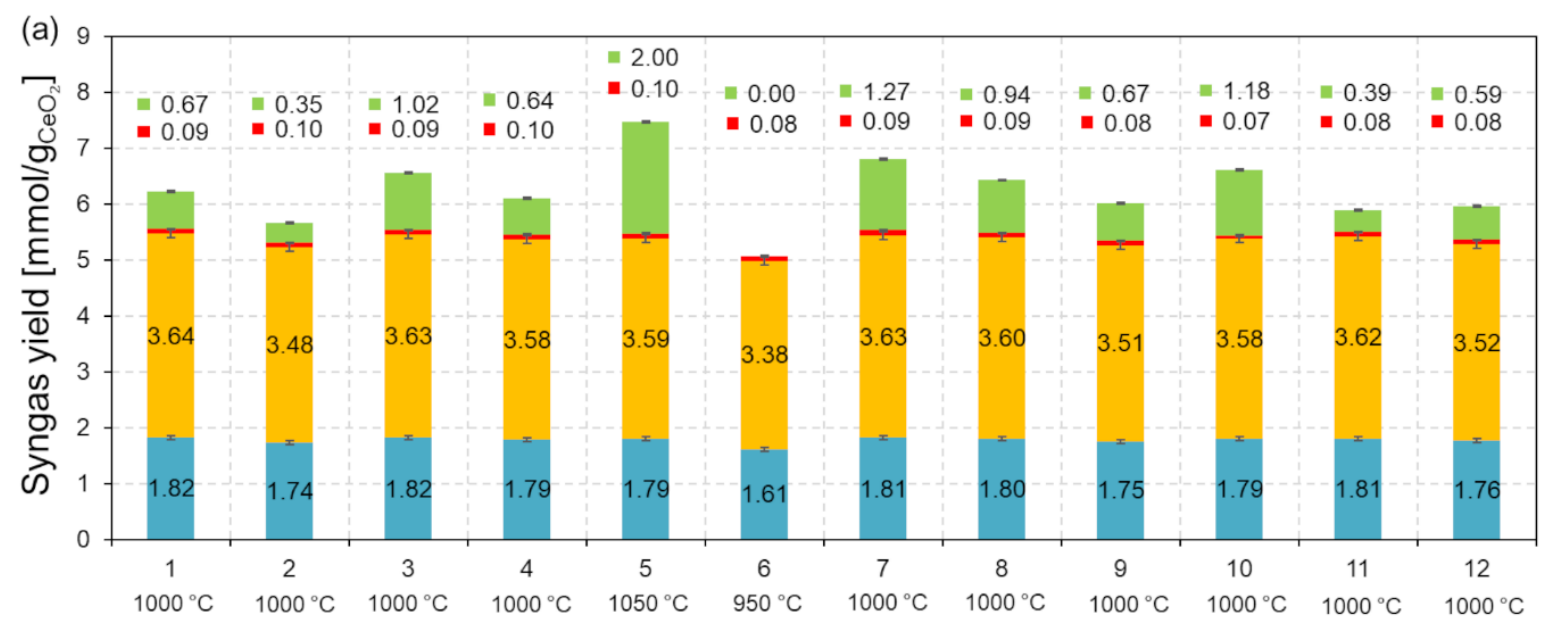

Cycle [-]

(b)

$=\mathrm{CO}\left(\mathrm{CeO}_{2}+\mathrm{CH}_{4}\right)=\mathrm{H}_{2}\left(\mathrm{CeO}_{2}+\mathrm{CH}_{4}\right)=\mathrm{CO}_{2}\left(\mathrm{CeO}_{2}+\mathrm{CH}_{4}\right)=\mathrm{H}_{2}\left(\mathrm{CH}_{4}\right.$ Cracking $)$

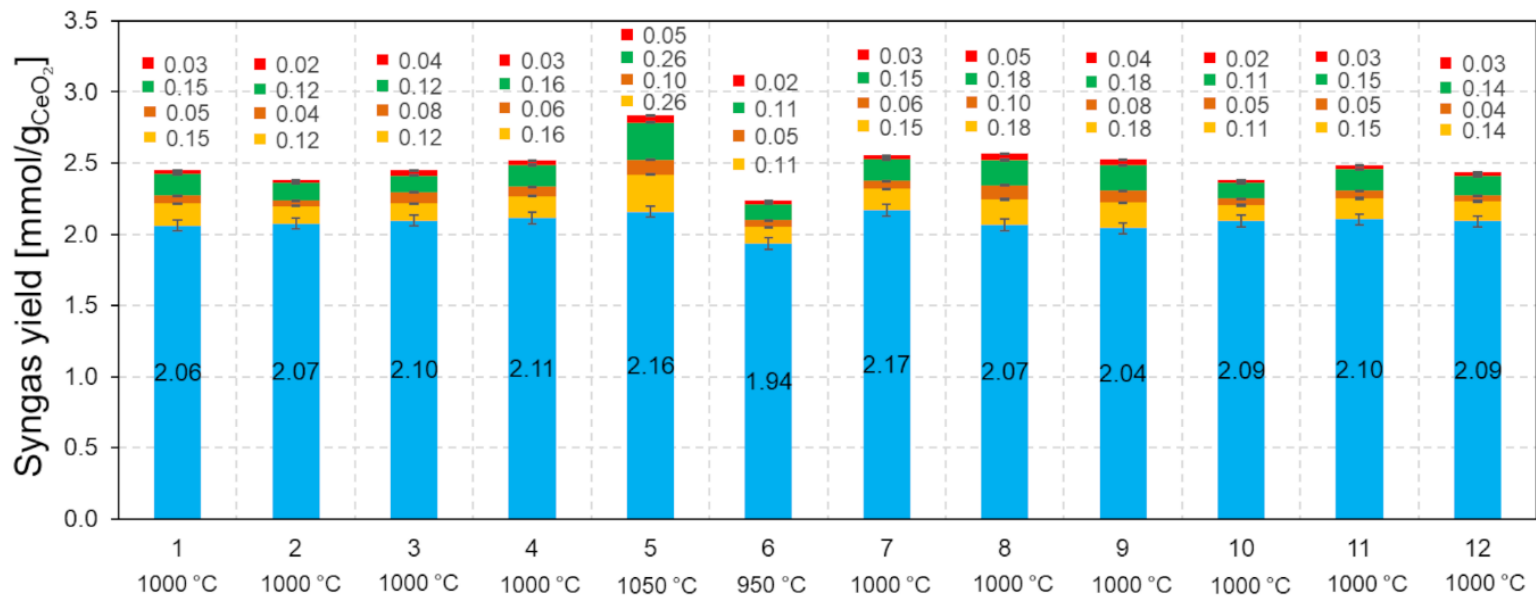

Cycle [-]

$\square \mathrm{H}_{2}\left(\mathrm{CeO} 2-\delta+\mathrm{H}_{2} \mathrm{O}\right) \quad=\mathrm{H}_{2}\left(\mathrm{C}+\mathrm{H}_{2} \mathrm{O}\right) \quad \square \mathrm{H}_{2}\left(\mathrm{C}+2 \mathrm{H}_{2} \mathrm{O}\right) \quad \square \mathrm{CO}\left(\mathrm{C}+\mathrm{H}_{2} \mathrm{O}\right) \quad \square \mathrm{CO}_{2}\left(\mathrm{C}+2 \mathrm{H}_{2} \mathrm{O}\right)$

Figure 13. Syngas yields for both reduction and re-oxidation of ceria porous foam during 12 consecutive redox cycles performed isothermally. 


\section{WILEY-VCH}

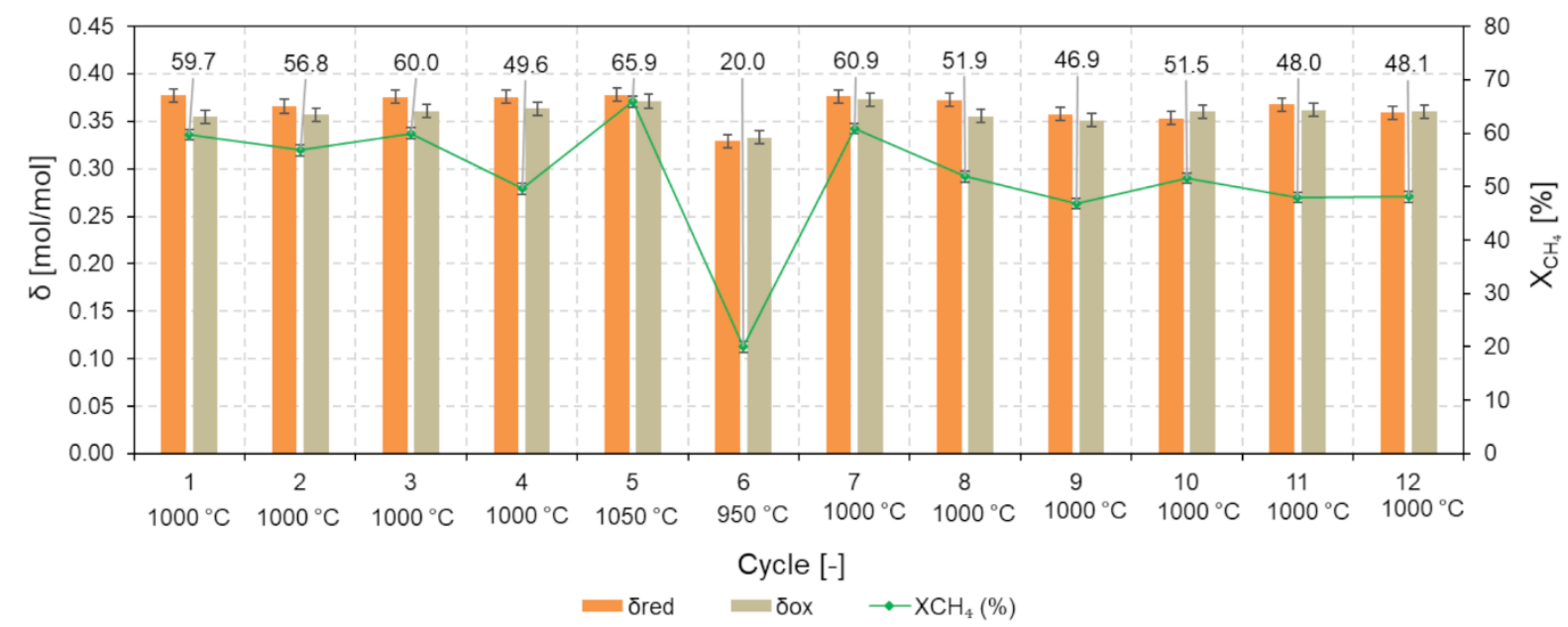

Figure 14. Comparison of $\delta_{\text {red }}$ and $\delta_{\text {ox }}$ in ceria foam along with $\mathrm{CH}_{4}$ conversion during 12 consecutive redox cycles performed isothermally.

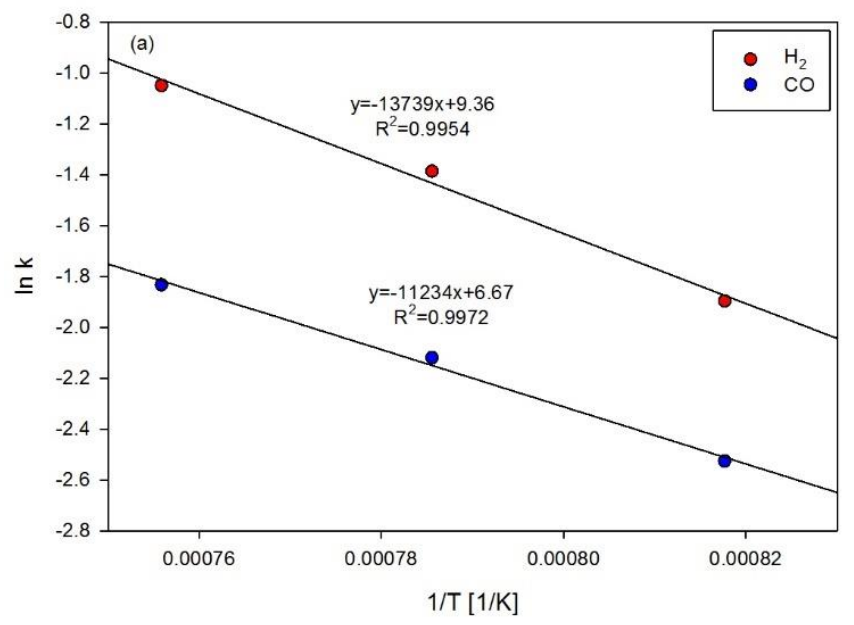

Figure 15. Arrhenius plot for $\mathrm{H}_{2}$ and $\mathrm{CO}$ production rates in the range $950-1050{ }^{\circ} \mathrm{C}$ during ceria foam reduction. 


\section{WILEY-VCH}

Syngas is produced in a solar chemical reactor using reversible cycling of solid oxides for isothermal alternating methane reforming and $\mathrm{H}_{2} \mathrm{O}$ splitting. Solar chemical looping reforming using oxygen carrier materials promotes methane valorization and offers an efficient means of storing intermittent solar energy into renewable clean fuels.

\section{Solar fuels}

S. Chuayboon, S. Abanades", S. Rodat

Stepwise solar methane reforming and water-splitting via lattice oxygen transfer in iron and cerium oxides

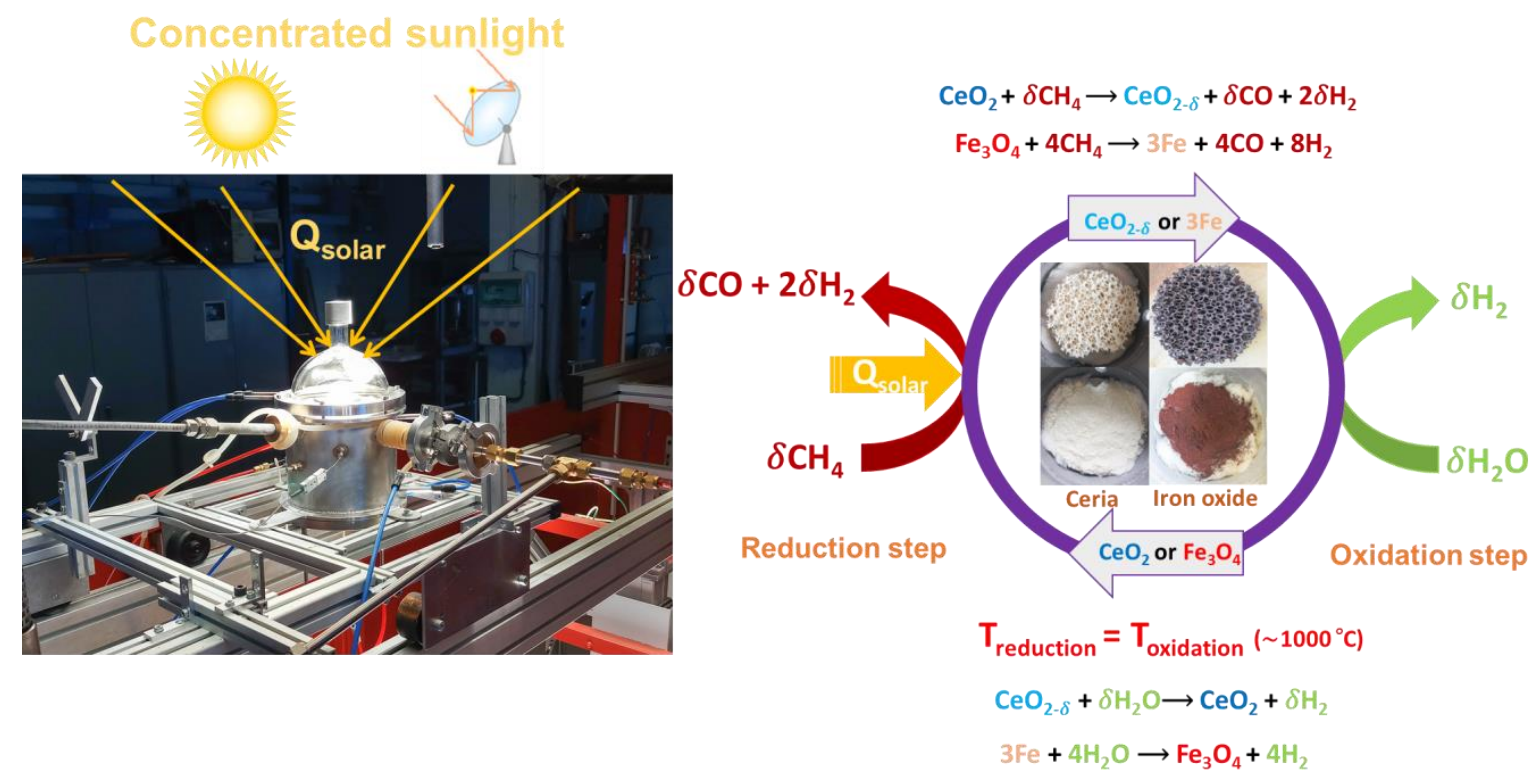

